\title{
The Universal Declaration of Human Rights and the Modern History of Human Rights
}

\author{
Fengyu Duan
}

October 15, 2017

\begin{abstract}
Beginning with the phrase "all human beings are born free and equal in dignity and rights," the Universal Declaration of Human Rights (UDHR) proclaims its purpose of establishing global human rights from the outset. As a common standard of achievement for all signatory nations, the UDHR constitutes an essential cornerstone in the modern history of human rights by drawing upon ancient to contemporary philosophies, responses to the heinous crimes of World War II, and various visions for future human rights standards. Despite diverging viewpoints from many of the drafting parties and states, the UDHR eventually transcended conflict to form the underpinnings of a moral compass for all of humankind.

This essay first explores how the UDHR came into formation by reviewing the historical origins of human rights, global dynamics prior to the UDHR, the drafting process and key debates involved, and finally its achieved compromise and ultimate unanimous adoption. Then, the essay examines ways in which the UDHR has evolved, from both a legal and moral angle, since its adoption in the context of past achievements and current challenges. From a historical point of view, I argue that the UDHR is a living document that has and is expected to change as our societies continue to evolve.

:TAXONOMY:.

/law, government and politics/legal issues/human rights (0.662526); /society/unrest and war (0.182124); / law, government and politics [top level] (0.167871)

Keywords: human rights, human rights project, international human rights, UDHR, Universal Declaration of Human Rights, human rights standards, Human Rights Commission, global human rights, future human rights, United Nations, United States Declaration of Independence, political rights, economic rights, social rights
\end{abstract}

JEL Classifications: K38, K33, Z13, Z18, N40, K19 


\section{Contents}

1 The Historical Origins of Human Rights . . . . . . . . . . . . . . . . 3

2 Global Dynamics Preceding the UDHR's Drafting . . . . . . . . . . 7

3 The Drafting of the UDHR . . . . . . . . . . . . . . 11

4 Lingering Debates . . . . . . . . . . . . . . . . . . 15

5 Overcoming Barriers and Obtaining Adoption . . . . . . . . . . . 19

6 Legal Significance of the UDHR . . . . . . . . . . . . . . . . . 22

7 Moral Significance of the UDHR . . . . . . . . . . . . . . . . . 28

8 Challenges, Criticism, and Counterargument . . . . . . . . . 34

8.1 Enforceability . . . . . . . . . . . . . . . . . 34

8.2 Cultural Relativism . . . . . . . . . . . . . . . . . 36

9 Conclusion . . . . . . . . . . . . . . . . . . . 39

10 Bibliography . . . . . . . . . . . . . . . . . . . 40 


\section{The Historical Origins of Human Rights}

The origins of human rights are by no means simple; they emerged and evolved in intricate ways in distinct historical settings. ${ }^{1}$ However, these origins can be roughly categorized into three primary categories: religious contemplations, philosophical inspirations, and political and social theories.

Initially, the ancient worship of diverse religions led to early human rights practices. ${ }^{2}$ Given that religious grounds for human rights involve a myriad of complexities, only a few select moments will be examined here. In the West, Judaism, a religion established more than 3,500 years ago, has primarily emphasized the performance of duty, a notion that may further promote respect for one's rights. ${ }^{3}$ For example, Leviticus, the third book of the Hebrew Bible, explicitly commands, "You shall not oppress. You shall do no injustice. You shall love your neighbors as yourself." 4 These instructions establish responsibility toward others. Stemming from Judaism, Christianity endows human dignity with universality, a concept that is central in human rights today. ${ }^{5}$ Shattering divisions based upon ethnicity, social status, and gender, Christianity acknowledges that we "are all one in Christ Jesus." 6

In the East, Hindu social ethics, which emerged around the fifth century B.C.E., connect the notion of duty with specific legal, political, and economic rights. ${ }^{7}$ However, such ideals rest on the belief of spiritual development, or transcendence. ${ }^{8}$ Sharing with Hinduism the pursuit of liberation from the material world, Buddhism, established in the sixth century B.C.E., not only assigns dignity and moral responsibility to human nature but also rejects the caste system and claims equality for all human beings. ${ }^{9}$ Islam, established in the seventh century C.E. and founded on the Judeo-Christian tradition, affirms the universality of human rights, proclaiming that "Jews [and, later, Christians] ... shall practice their religion as freely as Muslims." 10

Religious visions have thus made crucial contributions to the progress of international human rights by establishing moral codes, suggesting what ought to be, constructing responsibility toward others, and associating duties and rights. ${ }^{11}$ Conversely, philosophical visions seek to interpret human rights through reasoning, often followed by political and social revolutions.

1. Paul Gordon Lauren, The Evolution of International Human Rights: Vision Seen (Philadelphia: University of Pennsylvania Press, 2011), 5.

2. John Witte, Jr., "Law, Religion, and Human Rights," Columbia Human Rights Law Review 28, no. 1 (1996): 13.

3. Asber Maoz, "Can Judaism Serve as a Source of Human Rights?," Heidelberg Journal of International Law 64 (2004): 686.

4. Lev. 19:13, 15, 16. Authorized Version.

5. Michael Novak, "The Judeo-Christian Foundation of Human Dignity, Personal Liberty, and the Concept of the Person," Journal of Markets \& Morality 1, no. 2 (1998): 107-121.

6. Galatians 3:28. AV.

7. John Witte, Jr., "Religion," in The Oxford Handbook of International Human Rights Law, ed. Dinah Shelton (New York/Oxford: Oxford University Press, 2013), 9-31.

8. Ibid.

9. Damien Keown, "Are There "Human Rights" in Buddhism?", Buddhism and Human Rights 2 (1998): 15.

10. Iftikhar Ahmed Mehar, Al-Islam: Inception to Conclusion (Bloomington: Authorhouse, 2003), 185.

11. Lauren, The Evolution of International Human Rights, 10. 
Prominent civilizations across the globe have bred their own perspectives on human rights. Dating back to approximately 1780 B.C.E., the Babylonian Code of Hammurabi invokes progressive justice and condemns the arbitrary use of power to ensure the protection of human rights. ${ }^{12}$ In the sixth century B.C.E., Confucian philosophy took human rights as the "basis for a legitimate social and political order."13 As a typical representative of Eastern wisdom, Confucianism espouses many ideas related to human rights, including conscience, human dignity, morality over personal interest, and social harmony. ${ }^{14}$ Roughly contemporary to Confucianism, texts on the Cyrus cylinder, developed by ancient Persia's (now Iran's) ruler Cyrus the Great, are credited as the "earliest known advocates of religious tolerance" and sometimes even the "first charter of human rights" with the explicit appearance of the word "rights." 15,16 Other noteworthy contributors in the East include the Indian philosopher and prime minister Kautilya of the fourth century B.C.E. and the Islamic philosopher Abu Al-Farabi of the tenth century C.E. ${ }^{17}$

A continent away, the Greek classical era from 476 to 336 B.C.E. witnessed the birth of the world's first democracy with citizens granted civil and political rights within citystates. ${ }^{18}$ Several Greek philosophers, including Socrates, Plato, and Aristotle, argued for "a universal law of nature" that applied to all creation and provided the foundations for natural rights. ${ }^{19}$ Later, the Roman Stoics systematically advanced and promulgated natural rights by supporting the values of impartiality, egalitarianism, and cosmopolitanism. ${ }^{20}$ During the thirteenth century C.E., the Christian philosopher Saint Thomas Aquinas further polished Aristotle's concept of natural law. ${ }^{21}$ The Renaissance, an intellectual movement that prevailed in the fourteenth and fifteenth centuries C.E., spread the ideals of humanism and free expression that had previously been undermined by political and religious authorities. ${ }^{22}$

The concepts of natural laws and natural rights have evolved and shaped the political spheres as well. In 1215 C.E., the Magna Carta was issued and, for the first time, exerted legal restraints upon King John of England to protect certain liberties and the due process

12. Micheline R. Ishay, The History of Human Rights: From Ancient Times to the Globalization Era (Berkeley: University of California Press, 2008), 28.

13. Joseph C. W. Chan, "Confucianism and Human Rights," in Religion and Human Rights: An Introduction, ed. John Witte, Jr. and M. Christian Green (New York: Oxford University Press, 2011), 93.

14. Pinghua Sun, "Confucian Philosophy and Its Historical Contributions to Human Rights," in Human Rights Protection System in China (New York: Springer, 2014), 1-20.

15. W. J. Talbott, Which Rights should be Universal? (Oxford: Oxford University Press, 2005), 40.

16. Sabine C. Carey, The Politics of Human Rights: The Quest for Dignity (Cambridge: Cambridge University Press, 2010), 19.

17. Lauren, The Evolution of International Human Rights, 12.

18. Jack Donnelly, Universal Human Rights in Theory and Practice (Ithaca: Cornell University Press, 2013), 81.

19. Aristotle, Aristotle: In Twenty-Three Volumes, trans. J. H. Freese (Cambridge and London: Harvard University Press, 1926), Book I, Chapter 13.

20. Lisa Hill, "Stoic Cosmopolitanism and the Birth of Universal Rights," American Political Science Association 2013 Annual Meeting Paper (2013): 27.

21. Ralph McInerny and John O'Callaghan, "Saint Thomas Aquinas," The Stanford Encyclopedia of Philosophy, Winter 2016, accessed September 1, 2017, https://plato.stanford.edu/entries/aquinas/.

22. C. B. Schmitt, The Cambridge History of Renaissance Philosophy (Cambridge: Cambridge University Press, 1988), 53. 
of law. ${ }^{23}$ In 1628, as a result of political disturbances from the same monarch, the Petition of Right was created, listing various civil liberties upon which the king could not infringe. ${ }^{24}$ In 1689, the English Bill of Rights constituted one of the milestones in the history of civil and political liberties, delineating free elections, open speech within parliament, and judicial justice as privileges for all citizens. ${ }^{25}$

Soon after, the Enlightenment of the seventeenth to eighteenth centuries C.E., a vigorous European intellectual movement emphasizing human reason and individualism, added vitality to the ideals of human rights. The English philosopher John Locke employed the theory of natural law to build upon the theory of natural rights, which he argued should include "life, liberty, and possessions." 26 The German philosopher Immanuel Kant, sometimes praised as the "giant shoulders [upon which] the modern theory of human rights rests," stated that humans' freedom to choose made them distinct from other beings. ${ }^{27} ;{ }^{28}$ Along with the efforts of other Enlightenment philosophers, these ideals inspired American and French Revolutionary thinkers and thus the following groundbreaking documents: the U.S. Declaration of Independence in 1776, the French Declaration of the Rights of Man and of the Citizen in 1789, and the U.S. Bill of Rights in 1791. These documents strove to affirm human rights, sometimes offering legal protections for fundamental liberties and launching the historical beginning of the constitutional movement and modern era. ${ }^{29}$ The voice of feminism and the rights of women also first became prominent following these revolutions. In 1791, the French political activist Olympe de Gouges challenged patriarchal traditions in her Declaration of the Rights of Women and the Female Citizen, announcing that "woman is born free and remains equal to man in her rights." 30

The evolution of human rights is too complex to detail in its entirety, with many setbacks along the way. Among the serious threats to human rights were the institution of slavery, gender inequality, and racial prejudice. Nevertheless, these early origins supply an essential foundation for the development of international human rights (best exemplified through the drafting of the UDHR) and illuminate the development of perceived natural rights for all of humankind. ${ }^{31}$

The thoughts and documents reviewed here eventually formed the foundations of the UDHR, which, for the first time, presented a transnational commitment to defining and protecting human rights. For instance, the Magna Carta is credited with being the "most direct ancestor of the actual language" in the UDHR, whereas the U.S. Bill of Rights served

23. Peter Linebaugh, The Magna Carta Manifesto: Liberties and Commons for All (Berkeley: University of California Press, 2008), 368.

24. "A British Bill of Rights: Informing the Debate," JUSTICE Constitution Committee of British Section of the International Commission of Jurists, 2007, accessed September 1, 2017, http://www. statewatch. org/news/2007/nov/uk-justice-bill-of-rights-rep.pdf.

25. Ibid.

26. John Locke, Locke: Two Treaties of Government student edition (Cambridge: Cambridge University Press, 1988), Chap. VII, 87.

27. Michael Rosen, Dignity: Its History and Meaning (Cambridge, MA: Harvard University Press, 2012), 19.

28. Samuel Moyn, Human Rights and the Uses of History (New York and London: Verso, 2014), 65.

29. Reis Monteiro, Ethics of Human Rights (Heidelberg: Springer International Publishing, 2014), 66.

30. Olympe de Gouge, "Declaration of the Rights of Women and the Female Citizen." College of Staten Island Library: American Studies Program (1791): Article I.

31. Lauren, The Evolution of International Human Rights, 23. 
as one of the previous models upon which the drafting of the UDHR heavily depended. ${ }^{32}$ Furthermore, the diverse range of perspectives proves an imperative point: the UDHR rests not only upon Western notions but also upon those originating in the East. Many principles that the UDHR espouses can be found in the world's great religious and philosophical traditions without distinction of East or West. Thus, at least theoretically, a document was created that is universally applicable to all. ${ }^{33}$ Although it is a relatively recent document, the UDHR's essence is deeply rooted in a diverse range of histories, making it, at least theoretically and idealistically, relevant to all of humankind.

32. Susan Muaddi Darraj, Milestones in Modern World History: The Universal Declaration of Human Rights (Langhome: Chelsea House, 2010), 49.

33. Douglas Irvin-Erickson, "Protection from Whom? Tensions, Contradictions, and Potential in the Responsibility to Protect," in Rethinking Security in the Twenty-First Century, ed. Daniel Jacob (New York: Palgrave Macmillan, 2017), 112. 


\section{Global Dynamics Preceding the UDHR's Drafting}

Although the early roots of human rights in the religious, philosophical, and political arenas intersected, offering a wide range of perspectives fundamental to the development of civil liberty as a concept, no global benchmark for human rights was established until the end of World War I. The Treaty of Versailles in 1919 led to the creation of the League of Nations and the International Labor Organization, two of the first international organizations, which aimed to achieve peace and encourage social justice, respectively. ${ }^{34}$ The new global order signified an important development in international human rights. The Covenant of the League of Nations promised "fair and humane conditions for labor," "just treatment," especially for persons of formerly colonized territories and members of minority groups, as well as "freedom of conscience and religion." 35 However, the notion of international protection for human rights was never seriously considered or acknowledged by the global community despite Japan's efforts to include racial equality and nondiscrimination clauses. ${ }^{36}$

In 1929, the Institut de Droit International (Institute of International Law), a wellrespected global law organization, drafted and adopted the Declaration of the International Rights of Man at its meeting in New York. This document proclaimed the "equal rights of every individual to life, liberty, and property" without a basis in any particular nationality, gender, language, or religion. ${ }^{37}$ René Cassin, a vital figure in the subsequent drafting of the UDHR, credited the Declaration of the International Rights of Man as one of his influences. ${ }^{38}$

Ironically, it was the outbreak of World War II and its many casualties that called increased attention to the cause of human rights. From 1939 to 1945, the total number of deaths from WWII, including Allied and Axis soldiers and civilians, was estimated to exceed 60 million people, making it the deadliest conflict in human history. ${ }^{39}$ In Nazi concentration camps, up to 11 million Jewish, Roma, Soviet prisoners of war, homosexuals, and other victims were systematically killed. ${ }^{40}$ Atrocities within and apart from the Holocaust included sexual violence, forced labor, mass bombings, and human experimentation. Vowing "Never Again," the global community committed itself to fostering international

34. Lee Swepston, "The International Labour Organization and International Human Rights System," in Routledge Handbook of International Human Rights Law, eds. Scott Sheeran and Sir Nigel Rodley (London and New York: Routledge, 2013), 340.

35. "The Covenant of the League of Nations," The Avalon Project at the Yale Law School: Documents in Law, History and Diplomacy (New Haven: The Avalon Project, December 1924), accessed September 1, 2017, http://avalon.law.yale.edu/20th_century/leagcov.asp.

36. Thomas Buergenthal, Dianh Shelton, and David P. Stewart, "International Human Rights in a Nutshell," George Washington Legal Studies Research Paper no. 2013-34 (2009): 8.

37. Institut de droit international, "Declaration of the International Rights of Man," American Journal of International Law 35 (1941): 664.

38. William A. Schabas, "The Rights to Life," in Oxford Handbook of International Law in Armed Conflict, eds. Andrew Clapham and Paola Gaeta (Oxord: Oxford University Press, 2014), 367.

39. Donald Sommerville and Ian Westwell, The Complete Illustrated History of World War II: An Authoritative Account of One of the Deadliest Conflicts in Human History, with Analysis of Decisive Encounters and Landmark Engagements (London: Lorenz Books, 2008), 5.

40. Darraj, Milestones in Modern World History, 17. 
cooperation to prevent such atrocities against humanity from ever occurring in the future. ${ }^{41}$

This collaboration proceeded slowly and systematically. One of the first notable humanitarian responses to the brutal war came from US President Franklin D. Roosevelt. His Four Freedoms proposal in January 1941 identified the basic liberties to which all persons were entitled as those of speech, religion, a lack of want, and an absence of fear, with "supremacy of human rights everywhere." ${ }^{2}$ Roosevelt's Four Freedoms proved to be rather influential; they were later incorporated into the preambles of the UDHR and other prominent human rights documents. In August of the same year, Roosevelt and British Prime Minister Winston Churchill drafted the Atlantic Charter, in which they affirmed the principle of self-determination and envisioned a bright future for the world where "all men in all lands may live out their lives in freedom from fear and want" after defeating the Axis Powers. ${ }^{43}$ In January 1942, a joint announcement of the Allies, the Declaration of the United Nations, was signed by the US, UK, USSR, China, and 22 other states, upholding and expanding upon the Atlantic Charter. ${ }^{44}$ Since that key moment in history, the crusade for human rights has been integrated into a transnational commitment to combat fascism. ${ }^{45}$ Together, the Atlantic Charter and the Declaration of the United Nations marked the official entry of human rights as a topic of international discussion. ${ }^{46}$

This faith in and enthusiasm for human rights, however, eventually began to fade. Each of the involved states violated the pledge of protecting human rights embedded in the Atlantic Charter and the Declaration of the United Nations at some point in their subsequent history, from the repressive regime of Stalin in the USSR, to continued British colonialism, to racial and legal segregation in the US. ${ }^{47}$ None of these powers seemed ready to adjust their policies to meet the standards of human rights principles; thus, these principles remained largely idealistic. ${ }^{48}$ The former Allies also feared intervention by less-powerful states and the loss of supremacy that might result from prioritizing human rights over national interest. ${ }^{49}$ Not surprisingly, these powers considered the human rights project peripheral. ${ }^{50}$ At the Dumbarton Oaks Conference of 1944, an exclusive meeting to negotiate and create a new global order, the United States suggested that respect for individual rights should be the basis of UN membership obligation, effectively eliminating

41. Jide Nzelibe, "Courting Genocide: The Unintended Effects of Humanitarian Intervention," Northwestern University School of Law, Public and Legal Theory Series 8, no. 36 (2008): 3.

42. Franklin D. Roosevelt, "Message to Congress," January 6, 1941, accessed September 1, 2017, https: //fdrlibrary.org/four-freedoms.

43. Franklin D. Roosevelt and Winston S. Churchill, Atlantic Charter (New York: John Wiley \& Sons, Ltd., 1941), Chapter B, 2.

44. Franklin D. Roosevelt, "The Pubic Papers and Addresses of Franklin D. Roosevelt: Humanity on the Defensive," American Historical Review 55, no. 4 (1942): 3-5.

45. M. Glen Johnson and Janusz Symonides, The Universal Declaration of Human Rights: A History of Its Creation and Implementation 1948-1998 (Paris: UNESCO Publishing, 1998), 27.

46. Roger Normand and Sarah Zaidi, Human in the U.N.: The Political History of Universal Justice. United Nations Intellectual History Project (Bloomington: Indiana University Press, 2008), 94.

47. Wiktor Osiatynski, Human Rights and Their Limits (Cambridge: Cambridge University Press, 2009), 15.

48. Normand and Zaidi, Human in the U.N., 46.

49. Osiatynski, Human Rights and Their Limit, 187.

50. M. A. Glendon, A World Made New: Eleanor Roosevelt and the Universal Declaration of Human Rights (New York: Random House, 2001), 4-20. 
the possibility of such liberties being extended to non-member states. Furthermore, the USSR and the UK rejected the Chinese proposal for racial equality and eliminating bias based upon ethnic identity from the final statement, the Proposals for the Establishment of a General International Organization. ${ }^{51}$ Ultimately, the proposals included only a cursory and unenforceable reference to universality: the newly formulated international organization would simply "promote respect for human rights and fundamental freedoms." 52

However, WWII and the human rights promises that followed its conclusion awakened public and international demand for substantial action in the postwar global order. However, the absence of meaningful human rights principles in the plans for the new organization soon enraged smaller states, triggering persistent criticism. This dissatisfaction was particularly evident among many Latin American states, leading to the Inter-American Conference on Problems of War and Peace in February 1945. With primary concerns including the principles of sovereignty and non-intervention, the conference declared adherence to a system of international protection for human rights as well. ${ }^{53}$

Simultaneously, the concept of liberalism, a political philosophy that values individual rights and liberties above all, began gaining popularity throughout the world. This political philosophy also invested in creating "a more humane world." ${ }^{54}$ Leading organizations that espoused this philosophy included what are now known as nongovernmental organizations (NGOs), private companies, and individuals who worked vigorously toward developing a new mechanism for international morality. ${ }^{55}$

The combined influence of these smaller powers, international NGOs, private businesses, and prominent individuals managed to subvert the former Allied powers' plans to emphasize only the rights of specific groups of people. ${ }^{56}$ In April 1945 at the San Francisco Conference of the United Nations, many states, including Panama, Chile, South Africa, and Mexico, offered proposals to include human rights provisions in the Charter of the UN; the determined lobbying of various NGOs, led by the American Jewish Committee, also made significant contributions. ${ }^{57}{ }^{58}$ As a result of these efforts, the UN Charter included the promotion of "respect for human rights and for fundamental freedoms for all" and mandated the establishment of a Commission on Human Rights within the Economic and Social

51. Cathal J. Nolan, "Road to the Charter: America, Liberty, and the Founding of the United Nations," Paradigms 3, no.1 (1989): 29.

52. "Proposal for the Establishment of a General International Organization, Pamphlet No. 4, Pillars of Peace," in Documents Pertaining to American Interest in Establishing a Lasting World Peace: January 1941-February 1946 (Fort George G. Meade: Army Information School, 1946), Chapter IX, 36.

53. Ann Van Wynen Thomas and A.J. Thomas Jr., "Human Rights and Organizations of American States," Santa Clara Lawyer 12 (1972): 319.

54. Allida M. Black, Casting Her Own Shadow: Eleanor Roosevelt and the Shaping of Postwar Liberalism (New York: Columbia University Press, 1996), 1.

55. Roger Baldwin, "International Agreements Can Protect Specific Rights," Annals of the American Academy of Political and Social Science 243, no. 1 (January 1946): 134-138.

56. Joe Hoover, "Rereading the Universal Declaration of Human Rights: Plurality and Contestation, Not Consensus," Journal of Human Rights 12 (2013): 217-241.

57. Dominic McGlodrick, The Human Rights Committee: Its Role in the Development on Civil and Political Rights (Oxford: Clarendon Press, 1991), 3-4.

58. William Korey, NGO's and the Universal Declaration of Human Rights: A Curious Grapevine (London: Palgrave Macmillan, 2004), 2. 
Council. ${ }^{59}$ However, the charter also outlawed any UN intervention on matters within the "domestic jurisdiction of any state," in practice projecting barriers of enforcement on human rights issues. ${ }^{60}$ This strategy, proposed by the US, was perhaps intended to minimize challenges to the human rights provision. However, revealing the controversy between sovereignty of state and the enforceability of human rights has long since remained the crux of the debate. ${ }^{61}$

The passage of the UN Charter in June and the subsequent establishment of the UN not only marked a significant turning point in world politics and international relations but also provided an unprecedented framework for international human rights protections. Despite reluctance from some states, the highest ideals of humanity, persistently invoked by smaller powers and civil society, would thereafter extend, at least theoretically, beyond national borders. Thus, the world entered into the newly established order of a global community that hoped to prevent the offenses of totalitarianism from occurring again.

59. "U.N. Charter," The United Nations, accessed September 1, 2017, http://www . un. org/en/sections/ un-charter/chapter-i/index.html.

60. Ibid.

61. Normand and Zaidi, Human in the U.N., 132. 


\section{The Drafting of the UDHR}

Shortly after the UN Charter came into effect, on November 23, 1945, the Executive Committee of the Preparatory Commission of the UN, which was responsible for presiding over the first session of the UN's primary organs, mandated that "an international bill of rights" be formed. ${ }^{62}$ This requirement became the starting point for the drafting of the Universal Declaration of Human Rights.

However, the various meanings of the term "international bill of rights" triggered controversy that perplexed those involved in drafting the UDHR. They found that there were three possible approaches to the bill: the first was a morally compelling declaration, the second a legally binding document, and the third, regarding implementation, an international institution to protect human rights. ${ }^{63}$

In February 1946, the first session of the Economic and Social Council (ECOSOC) established a temporary Commission on Human Rights, which was charged with proposing suggestions for a permanent Commission on Human Rights. ${ }^{64}$ With Eleanor Roosevelt as chairperson and nine other distinguished members working collaboratively, the commission offered several suggestions as "preparatory work" for the development of the International Bill of Rights. ${ }^{65}$ The bill, as these members expected, "might become one of the cornerstones" upon which world peace would rest and would be drafted by the full commission as soon as possible. ${ }^{66}$ In this regard, they suggested a preference for a morally compelling declaration. ${ }^{67}$ This group proposed that the definitive commission comprise eighteen independent experts rather than governmental delegates. ${ }^{68}$ Furthermore, they suggested that the final commission should have roles not merely in drafting legal texts but also in monitoring the practice of human rights. ${ }^{69}$ Lastly, the commission envisaged "equitable geographical distribution" along with the guideline of "personal qualification" when considering nominees for the full commission, ensuring that larger and smaller states would have an equal say. ${ }^{70}$ This final suggestion was accepted, contributing to the perceived universality of the commission. ${ }^{71}$

However, the first three proposals of the temporary Commission were not followed. Complexities of the three different potential approaches to the International Bill of Rights

62. "Report of the Preparatory Commission of the United Nations," The United Nations, 1946, accessed September 1, 2017, http://dag.un.org/handle/11176/248329.

63. Johnson and Symonides, The Universal Declaration of Human Rights, 35.

64. Olivier De Schutter, International Human Rights Law: Cases, Materials, Commentary, (Cambridge: Cambridge University Press, 2014), 16.

65. United Nations, Report of the Commission on Human Rights to the Second Session of the Economic and Social Council, UN Doc. E/38, at 3 (1946).

66. Eleanor Roosevelt, "The Promise of Human Rights," Foreign Affairs (1948), 473.

67. United Nations, Report of the Commission on Human Rights to the Second Session of the Economic and Social Council, 6 .

68. Johannes Morsink, The Universal Declaration of Human Rights: Origins, Drafting, and Intent (Philadelphia: University of Pennsylvania Press, 1999), 4.

69. Phillip Alston, "The Commission on Human Rights," in The United Nations and Human Rights: A Critical Appraisal, 2nd ed. (Oxford: Oxford University Press, 2004), 126.

70. United Nations, Commission on Human Rights, Summary of Meetings, UN Doc. E/HR. 9, at 5 (1946).

71. Morsink, The Universal Declaration of Human Rights, 4. 
failed to be understood or addressed when the ECOSOC discussed the document's creation in its June meeting, at which the permanent Commission of Human Rights was established. Refusing to choose among the three projections for the bill, the ECOSOC instructed the provisional commission to work on all three simultaneously. Instead of independent experts, appointed to the commission were eighteen representatives of governments that included Australia, Belgium, Soviet Byelorussia (the BSSR), Chile, China, Egypt, France, India, Iran, Lebanon, Panama, the Philippines, the UK, the US, the USSR, Uruguay, and Yugoslavia. ${ }^{72}$ Therefore, the tone was set for highly varied national values and cultural norms that would shape the human rights project, which, to some extent, marginalized the role of the individual from a global perspective. ${ }^{73}$ Furthermore, the commission failed to invoke monitoring power until around the 1970s, meaning that they had little oversight over the fulfillment of human rights worldwide. ${ }^{74}$

The commission held its first session in January and February of 1947 and soon realized that a smaller group would be more effective at accomplishing a preliminary draft of the bill. Hence, it assigned the task to a drafting subcommittee under unanimous approval. ${ }^{75}$ Initially, the drafting subcommittee included only Eleanor Roosevelt of the US, who was elected the chair of the full commission, Peng-Chun (P. C.) Chang of China, its Vice President, and Charles Malik of Lebanon, the Repporteur, assisted by the UN Division of Human Rights, led by Secretariat Peters John Humphrey of Canada. ${ }^{76}$ The three members of the subcommittee entrusted Humphrey to prepare the first draft due to his vast legal expertise, his access to relevant resources, and his office's ability to conduct the necessary research. ${ }^{77}$ Synthesizing an extensive amount of human rights statements and suggestions by various governments, NGOs, and interested individuals, Humphrey attempted to "include all the rights mentioned" in his draft of the document. ${ }^{78}$ The comprehensiveness of the initial version of the UDHC surprised the drafting committee; it totaled more than 400 pages in length and contained 48 individual items, and it was later designated by the UN as "the most exhaustive documentation on the subject of human rights ever assembled."79 Humphrey's draft provided a solid basis for the UDHR, a masterpiece combining both existing models and emerging ideas from all over the globe. ${ }^{80}$

Meanwhile, the fourth session of the ECOSOC lasted from March to April. During this time, the decision was made to augment the drafting subcommittee to include five other delegates from Australia, Chile, France, the USSR, and the UK under the rationale that these additions would allow the drafting process to be more inclusive. The eminent team that nurtured the UDHR eventually included Eleanor Roosevelt, P. C. Chang, Charles Malik, René Cassin of France, and Secretariat Humphrey in the most influential roles.

72. Ibid.

73. Normand and Zaidi, Human in the U.N., 139.

74. Schutter, International Human Rights Law, 15.

75. Glendon, A World Made New, 45.

76. United Nations, Commission on Human Rights, Summary Record of the Twelfth Meeting, UN Doc. E/CN.4/SR.12, at 5 (1947).

77. Darraj, Milestones in Modern World History, 38.

78. United Nations, Drafting Committee of the Commission on Human Rights, Summary Record of the First Meeting, UN Doc. E/CN.4/AC.1/SR/1, at 5 (1947).

79. Glendon, A World Made New, 58.

80. Morsink, The Universal Declaration of Human Rights, 6 . 
Eleanor Roosevelt's skills in facilitating action and building consensus, along with her diligence, enthusiasm, and public standing, made her such an invaluable asset that Malik commented he could never imagine "how they could accomplish [the task] without her." 81 Chang and Malik stood as the intellectual giants of the subcommittee: Chang was a creative dispute mediator who frequently incorporated Confucianism into discourse, whereas Malik, a fastidious, unyielding man, approached the UDHR with foundations in natural law. ${ }^{82}$; ${ }^{83}$ Cassin, a considerate, easy-going man, brought much-needed academic and personal experience to the group and was awarded the Nobel Peace Prize for his contributions. ${ }^{84}$ Finally, equipped with distinguished expertise, Humphrey not only produced the first draft of the UDHR but also served to link multiple ideological perspectives. ${ }^{85}$ Other members included William Hodgson of Australia, Hernan Santa Cruz of Chile, Vladimir Koretsky (whose position was frequently replaced later in the process) of the USSR, and Geoffrey Wilson of Great Britain.

Ultimately, a compromise was reached, and two types of documents were prepared. This was the beginning of the fragmentation of the International Bill of Rights to include the more general UDHR as well as the more divisive International Covenant on Civil and Political Rights (ICCPR) and the International Covenant on Economic, Social and Cultural Rights (ICESCR). As a result of this schism, more of the subcommittee's attention was devoted to the drafting of the UDHR than to the International Bill of Rights as a whole. According to Roosevelt, the British draft of the ICCPR was far less deliberately crafted and reviewed than the UDHR and was eventually submitted to the commission as a mere report. 86.87

The tightly knit group of those working on the declaration, including Roosevelt, Cassin, Malik, and Wilson, entrusted Cassin personally with the development of a second draft based on Humphrey's earlier effort. Drawing three-quarters of its provisions from the Humphrey draft, Cassin framed his revisions as a logical rearrangement, made cautious revisions, and expanded upon the preamble to explain the necessity of the UDHR. ${ }^{88}$

Cassin's draft offered a vital step toward completion, and some even honored him, incorrectly, as the sole "father of Universal Declaration." 89 Reviewed and revised by the

81. A. Glenn Mower, Jr., The United States, the United Nations, and Human Rights: The Eleanor Roosevelt and Jimmy Carter Eras (Westport, Connecticut: Greenwood Press, 1979), 58.

82. Sumner Twiss, "Confucian ethics, concept-clusters, and human rights," in Polishing the Chinese Mirror: Essay in Honor of Henry Rosemont, ed. Jr., Marthe Chandler and Ronnie Littlejohn (New York: Global Scholarly Publication, 2007), 60-63.

83. Sol Linowitz, Charles H. Malik, and Daniel Parker, The Creative Interface: International Business-Governmental Relations, vol. 2 (Washington D.C.: American University Press, 1970), 3-48.

84. Kenneth Cmiel, "The Recent History of Human Rights," American Historical Review 109 (2004):123.

85. John P. Humphrey, On the Edge of Greatness: The Diaries of John Humphrey, First Director of the United Nations Division of Human Rights, vol. 1,1948-1949, ed. A. J. Hobbins (Montreal: McGill University Libraries, 1994), 88.

86. "Memorandum of Conversation between Mrs. Roosevelt, Senator Austin, and Messrs Ross, Winslow and Hendrick," in Box 4587, ER Paper (1947), 42.

87. United Nations, Report of the Drafting Committee to the Commission on Human Rights, UN Doc. E/CN.4/21, at 5 (1947).

88. Jay Winter and Antoine Prost, René Cassin and Human Rights: From the Great War to the Universal Declaration (Cambridge: Cambridge University Press, 2013), 246.

89. Ibid, 237. 
drafting subcommittee on June 17, 1947, Cassin's revisions were then submitted to the full commission in Geneva, Switzerland. In December, the larger Commission on Human Rights carefully reviewed the materials before engaging in numerous discussions. During this time, members of the commission took part in prolonged debates, eventually emerging with a third version of the document, referred to as the Geneva draft. Still, the commission continued its efforts on the three fronts - the declaration, the convention, and the measures for implementation. Despite the fact that there was only a rudimentary draft of the UDHR and little progress made toward revising the ICCPR and ICESCR, both were later completed, and the International Bill of Rights was born. ${ }^{90}$

90. James Frederick Green, The United Nations and Human Rights (Washington, D.C.: Brookings Institution, 1956), 25. 


\section{Lingering Debates}

Arguments regarding the purpose of the UDHR were largely driven by political dilemmas and ideological discrepancies, which interweaved with one another and created formidable hurdles. At the time, the wartime alliance against fascism was on the verge of fragmentation following Joseph Stalin's declaration in February 1946 that the coexistence of communism and capitalism was impossible. ${ }^{91}$ Winston Churchill delivered his famous Iron Curtain Speech one month later, warning that a "shadow... alike in the west and in the east falls upon the world." ${ }^{2}$ Meanwhile, in a long telegram, US diplomat George Kennan anonymously framed what would become known as the US containment policy against Soviet aggression. Together, these actions signaled increased tensions between the US and the USSR, two major superpowers in the world at the time, and, more broadly, the Eastern and Western Blocs. This anxiety would eventually lead to the conflict that became known as the Cold War, a period of geopolitical tension that has shaped the course of human rights to this day.

To fully understand the intriguing dynamics at play among UN member states, it is essential to remember that the delegates on the Human Rights Commission represented governments rather than independent persons, companies, or NGOs. As a result, these delegates were required to express opinions based upon political affiliation rather than personal belief. Roosevelt, for instance, constantly strove to include American ideals in the UDHR by taking advantage of her chairperson position. ${ }^{93}$ Although Roosevelt's arguments sometimes differed from those of the US State Department, she remained dedicated to serving US interests first and foremost. ${ }^{94}$ Due to her lobbying skills, her friendships with other subcommittee members, and her prestige and position within the UN along with the geopolitical powers of the US, almost all disagreements that emerged in the discussion were settled in favor of American interests. ${ }^{95}$

Therefore, intensified tensions between the U.S. and USSR permeated this transnational human rights project, to some extent changing the very notion of human rights into a philosophical weapon to be used against one's enemies in the decades-long Cold War. The US accused the USSR of human rights abuses, including religious prosecution, suppression of speech and press, as well as arbitrary and unjust trials. Similarly, the Soviet Union argued that the US was violating human rights standards as a result of race-based discrimination, lynchings, and other violence, both systemic and interpersonal, against African Americans, labeling the US a "hypocrite." 96

91. Joseph P. Stalin, "Speech Delivered by J. V. Stalin at a Meeting of Voters of the Stalin Electoral District," 1946, accessed September 1, 2017, https://www.marxists.org/reference/archive/stalin/ works/1937/12/election/index.htm.

92. Winston Churchill, "The Sinews of Peace ('Iron Curtain Speech')," International Churchill Society, March 5, 1946, accessed September 1, 2017, https://www. winstonchurchill.org/resources/speeches/ 1946-1963-elder-statesman/the-sinews-of-peace.

93. Kirsten Sellars, The Rise and Rise of Human Rights (Thrupp: Sutton, 2002), 18.

94. Alfred William and Brain Simpson, Human Rights and the End of the Empire: Britain and the Genesis of the European Convention (Oxford: Oxford University Press, 2004), 427.

95. Kirsten Sellars, The Rise and Rise of Human Rights, 23.

96. Carlos Iván Fuentes, René Provost, and Samuel G. Walker, "E Pluribus Unum-Bhinneka Tunggal Ika? Universal Human Rights and the Fragmentation of International Law," in Dialogue on Human Rights 
More complex still was the issue of ideological differences between the Western Bloc, the countries that supported the US and allied with NATO against the USSR, and the pro-Soviet Eastern Bloc, largely composed of socialist states that signed the Warsaw Pact. Holding individualism as a key value due to its unique history and traditions, the US vigorously encouraged the prioritizing of political and civil rights. ${ }^{97}$ Conversely, challenging the notion of individualism as the proper basis for human rights as an idea biased in favor of Western democracy, the USSR stated the necessity of "perfect harmony between the individual and the community," giving priority to the collective spirit of socialism and emphasizing economic and social rights. ${ }^{98}$

With these tensions in mind, Cassin crafted a draft that reflected a hierarchy of rights in line with the Western Bloc. Although he recognized economic, social, and cultural rights as important, he privileged their political and civil peers. He rationalized this decision by arguing that the latter rights (civil and political liberties) were more controllable on an international stage, whereas the former (economic, social, and cultural liberties) required national rather than international efforts for realization. ${ }^{99}$ Chang added another justification for this hierarchy of rights, arguing that such a perspective coincided with the chronological order in which rights historically developed. ${ }^{100}$ Although the Eastern Bloc opposed such arguments, they met with minimal success due to pressure from Roosevelt and pro-Western intellectuals such as Charles Malik and P. C. Chang.

Interestingly, on the issue of enforcement, the US and the USSR agreed, forming an anti-enforcement pact. Whereas the US argued that implementation should not be "an immediate, practicable objective," the Soviet Union openly voiced its opposition to enforcement measures, which, in their view, could disturb international relations and undermine peace efforts. ${ }^{101}$ As Malik noted, the issue of enforcement produced major disagreement between smaller and larger powers as well, with the former eagerly pursuing and the latter strongly objecting. ${ }^{102}$ As previously mentioned, this divisiveness resulted in the fragmentation of the International Bill of Rights into three separate items. This highly unpopular consequence among activists and the general public alike weakened the human rights project as a whole. ${ }^{103}$

Similarly, the issue of self-determination led to major conflict between larger and smaller powers. Primarily due to opposition from the US and the UK, this issue was essentially omitted from the UDHR. In the post-WWII era, nationalist movements emerged across the globe, particularly in Asian and African states that struggled to acquire independence and oust colonial powers. As a result, many of these would-be nations turned to the

and Legal Pluralism, ed. R. Provost and C. Sheppard (New York: Springer, 2013), 39.

97. Daniel A. Bell, East Meets West: Human Rights and Democracy in East Asia (Princeton: Princeton University Press, 2000), 5.

98. United Nations, Commission on Human Rights, Summary Record of the Eighth Meeting, UN Doc. E/CN.4/SR.8, at 4 (1947).

99. United Nations, Commission on Human Rights, Summary Record of the Seventy-Second Meeting, UN Doc. E/CN.4/SR.72, at 4 (1948).

100. Normand and Zaidi, Human in the U.N., 190.

101. William and Simpson, Human Rights and the End of the Empire, 426.

102. United Nations, Commission on Human Rights, Summary Record of the Twenty-Eighth Meeting, UN Doc. E/CN.4/SR.28, (1947).

103. René Cassin, La Pensée et l'Action (Paris: Lalou, 1972), 105-106. 
fundamental principles of human rights and self-determination for inspiration. ${ }^{104}$ However, dominated by greater powers that often also functioned as colonizers, the discussion of rights per the UDHR often excluded the voices of these suppressed groups despite the USSR's efforts to include the doctrine of self-determination in a series of amendments proposed at the last moment. ${ }^{105}$

Another political battlefield emerged as a result of ethnic conflict arising between Arab League states and Israel in May 1948. According to the "Partition Plan" produced in the UN General Assembly Resolution, the British Mandate over Palestine was to be terminated, resulting in two independent states - one Arab and the other Jewish — within the borders of what had previously been Palestine. ${ }^{106}$ The resolution triggered an outbreak of aggression as Arab nations attempted to use force, namely, the volunteer-based Arab Liberation Army, to thwart the creation of the new Jewish state of Israel. ${ }^{107}$ A firm Zionist, Cassin supported the establishment of Israel, which he believed would save his people from their plight as perpetual outsiders. ${ }^{108}$ This view put him in direct conflict with Malik, an Arabic man whose state, Lebanon, contributed substantially to the Arab Liberation Army. ${ }^{109}$ The political landscape became even more fraught over the summer with the Soviets' blockade in Berlin, the communists' support for unions in Italy and France, and Mao Tse-Tung's battle against nationalist forces in China. ${ }^{110}$

Thus, much compromise and discussion, to say the least, were required to develop the UDHR as a document that satisfied multiple ethnic viewpoints and philosophies held by the UN's diverse member states. In 1948, membership included more than 35 nations from Judeo-Christian traditions, 11 from Islamic traditions, 4 adherent to Buddhism and 1 to Hinduism as well as 6 other nations rooted in secular, communism-based ideologies. ${ }^{111}$ Because some semblance of agreement was desired, the UDHR would need to transcend differences in language, nationality, and culture to establish these foundational guidelines. Thus, the wording of the draft was continuously revised in an attempt to accommodate different perspectives. Some particular areas of dispute included the expression "brothers" in article 1, which some believed indicated sexism. ${ }^{112}$ Ultimately, the reference was changed to "in a spirit of brotherhood" rather than alternate proposals that included "members of the same family" and "in a spirit of brotherhood and sisterhood" because it was decided that such language "sufficiently expressed the idea advocated." 113

104. Roland Burke, Decolonization and the Evolution of International Human Rights (Philadelphia: University of Pennsylvania Press, 2010), 19.

105. United Nations, Union of Soviet Socialist Republic, Amendments to the draft Declaration proposed by the Third Committee, UN Doc. A/784 (1948).

106. United Nations, General Assembly, Official Record of the Second Session, UN Doc. A/519 (1947).

107. Asher Maoz, "War and Peace-An Israeli Perspective," Constitutional Forum 24, no. 2 (2005): 35.

108. Winter and Prost, René Cassin and Human Rights, 323.

109. Ibid, 336 .

110. Allida M. Black, "Eleanor Roosevelt and the Universal Declaration of Human Rights," OAH Magazine of History 22, no. 2 (2008): 35.

111. David Mayers, "Humanity in 1948: The Genocide Convention and Universal Declaration of Human Rights," Diplomacy \&3 Statecraft 26 (2015): 459.

112. William A. Schabas, editor. The Universal Declaration of Human Rights: The Travaux Preparatoires, vol. 1 (Cambridge: Cambridge University Press, 2013), ci.

113. United Nations, Commission on Status of Women, Summary Record of the Ninth Meeting, UN Doc. E./CN.6/SR.28, at 4 (1948). 
In addition, women's rights activists worked to forward their cause. Hansa Jivraj Mehta of India battled gender inequality in marriage, polygamy, and a sexist legal system while the American Eleanor Roosevelt simultaneously worked toward equal opportunities in the workplace and public life regardless of gender. ${ }^{114}$ However, Roosevelt, along with many other delegates, both male and female, believed that biological differences based upon sex meant that women should fulfill different roles from men, particularly when it came to the shaping of children's lives. ${ }^{115}$ As a result, the only two specific mentions of women in the UDHR include provisions for the "equal rights of men and women" in the preamble and the rights of men and women "to marry and to found a family" in article $16 .{ }^{116}$

Additionally, specific word choices addressing the origin of human rights caused disagreement, mainly questioning whether such liberties should be based upon religious or secular rationales. The delegation from Brazil proposed the notion of God as an explanation for human reason and conscience, whereas France and the Philippines submitted the phrase "by nature" and the Netherlands suggested "man's divine origin and immortal destiny."117 The Soviet Bloc, in contrast, claimed such language inappropriate, arguing against incorporating any religious notions into the UN document on the basis of it being a fundamentally secular organization. ${ }^{118}$ Eventually, Chang was able to facilitate a compromise; he reasoned that the term "nature" indicated both materialistic and spiritual aspects of humanity. In the end, no references to God or nature were included. ${ }^{119}$

During the second commission meeting in Geneva, in December of 1947, the UDHR underwent many drafts and was widely discussed due to a myriad of political and ideological opinions among delegates. However, as we shall see, these barriers did not completely hinder the progress of the project; rather, with certain common grounds established and some compromises made, the group overcame various difficulties to stand as a milestone for human rights.

114. Jane Adolephe, "The Holy See and the Universal Declaration of Human Rights: Working Towards a Legal Anthropology of Human Rights and Family," Ave Maria Law Review 343 (2006): 357.

115. Ibid.

116. "The Universal Declaration of Human Rights," Preamble; Article 16, 1.

117. Adolephe, "The Holy See and the Universal Declaration of Human Rights," 354.

118. United Nations, The Third Committee, Summary Record of the Hundred and Sixty-Fifth Meeting, UN Doc. A/C.3/SR.165, at 765 (1948).

119. Morsink, The Universal Declaration of Human Rights, 287. 


\section{Overcoming Barriers and Obtaining Adoption}

In the spring of 1948, feedback from various governments regarding the Geneva draft began pouring in to the commission. Many of these comments were minor, addressing minute details that certain states felt should be altered slightly for transparency. For example, Egypt suggested that it should be clarified that the economic and social rights enumerated in articles 23-26 should be exercised only if "the economic conditions and potentialities of each State permit." 120 Other nations raised concerns about the compatibility of the explicitly stated rights with their own national laws and traditions. For example, according to Swedish law, it was legally impossible for members of the Swedish State Church to relinquish their membership, which the government worried may conflict with the freedom of religion principle expressed in the UDHR. ${ }^{121}$

With these comments in hand, in a subcommittee meeting on May 3, 1948, Roosevelt urged the working group to proceed "as quickly as possible," focusing on the discussion of detailed terms and appealing against time-consuming theoretical conjecture. ${ }^{122}$ However, dissatisfied with setbacks to a pro-Soviet agenda, the delegate Pavlov of the USSR suggested that a completely new draft be prepared and that discussion be focused on broader principles. ${ }^{123}$ In his speech on May 4, Pavlov blatantly criticized the existing draft as "a serious mistake" due to its lack of warning against fascism and Nazism as well as the unguarded Western Bloc rhetoric on certain economic and social human liberties, such as the right to work and anti-discrimination. ${ }^{124}$ Pavlov's hostility outraged many subcommittee members, making cooperation even more difficult.

Under the guidance of Roosevelt and with the assistance of NGOs such as the World Jewish Congress and the American Federation of Labor, the drafting subcommittee began its tedious review of the document article by article. Beginning on May 24, the third session of the Human Rights Commission conducted another exhaustive examination of the UDHR. The group came to the consensus that there was no time to consider the question of implementation or the covenant in precise detail; instead, the group decided to forward a working draft to the commission that was expected to be completed later. ${ }^{125}$ Pavlov expressed dissatisfaction with the revised draft, maintaining that it was vague and ineffective, while simultaneously condemning the unwillingness of the commission to issue many of the USSR's proposals. ${ }^{126}$ This solution evidently alienated the USSR, causing

120. United Nations, Collation of the Comments of Government on the Draft International Declaration on Human Rights, Draft International Covenant on Human Rights and the Question of Implementation, UN Doc. E/CN.4/85, at 42 (1948).

121. United Nations, Report of the Drafting Sub-Committee Consisting of the Representatives of Chile, China, United States of America, Union of Soviet Socialist Republics, on Article 5, 6, 7, of the International Declaration on Human Rights, UN Doc. E/CN.4/82/Add.11, at 2 (1948).

122. United Nations, Second Session of Drafting Committee, Summary Record of the Twentieth Meeting, UN Doc. E/CN.4/AC.1/SR.20, at 1-2 (1948).

123. United Nations, Speech by Mr. A. N. Pavlov, Representative of the Union of Soviet Socialist Republics in the Drafting Committee of the Commission on Human Rights, UN Doc. E/CN.4/AC.1/29 (1948).

124. Ibid.

125. United Nations, Report of the Third Session of the Commission on Human Rights, UN Doc. E/800, at 5 (1948).

126. United Nations, Commission on Human Rights, Summary Record of Eighty-First Meeting, UN Doc. E/CN.4/SR.81, at 28 (1948). 
them to withdraw their support. ${ }^{127}$ Ultimately, the draft of the UDHR was approved by the full commission by 12 votes to zero, with 4 abstentions that included the Eastern Bloc Countries of the USSR, Yugoslavia, the BSSR, and Ukraine. ${ }^{128}$

Next, the draft was forwarded to the ECOSOC's seventh session in July and August, where it met with more impediments. At that time, the ECOSOC was overwhelmed by multiple tasks regarding other subjects on their agenda, making it difficult for the UDHR to receive adequate attention. ${ }^{129}$ Additionally, some delegates noted that the UDHR draft was far from perfected and regretted the absence of materials that would appear in the ICESCR and ICCPR, both of which resulted from tight time limitations. ${ }^{130}$ The delegation from New Zealand argued that the UDHR should not be adopted before careful reconsideration by the commission "in the light of detailed comments by government," which would take another year. ${ }^{131}$ i Furthermore, the Danish delegation argued that three weeks was an insufficient period of time for governments to consider the draft of such an important document. ${ }^{132}$ Pavlov, who was also part of the USSR delegation to the ECOSOC, reiterated his opinion that the document was "unsatisfactory" and "less comprehensive" than it ought to be, though he eventually agreed to send it to the General Assembly for further recommendations. ${ }^{133}$

Despite widespread suspicion, the president of the ECOSOC, none other than Malik himself, effectively facilitated the decision to transfer the draft to its next phase with unanimous approval. Held from September to December 1948 in Paris, the Third Committee, or the Social and Humanitarian Committee of the General Assembly, did not reach a consensus as easily. ${ }^{134}$ During this meeting, the Soviet Union contended that debate and voting regarding the UDHR was required and that the document should be discussed "article by article and line by line." ${ }^{135}$ Furthermore, the Soviet delegation proposed a series of last-minute amendments regarding the right to self-determination, the protection of national minorities, and the affirmation of electoral rights without discrimination. Partly owing to the diplomatic strength of Malik, who also chaired the proceedings of the Third Committee, the draft won approval by 29 to none, with 7 abstentions, after 85 lengthy meetings over a two-month period. ${ }^{136}$

At that time, the title of the document, previously referred to internally as the International Declaration of Human Rights, was changed to the Universal Declaration of Human Rights, as proposed by Cassin. Cassin argued that such a change would strengthen

127. United Nations, Economic and Social Council, Summary Record of the Two Hundred and Fifteenth Meeting, UN Doc. E/SR.215, at 659 (1948).

128. United Nations, Commission on Human Rights, Summary Record of Eighty-First Meeting, 29.

129. United Nations, Note by Representative of Canada, UN Doc. E/965 (1948).

130. United Nations, Economic and Social Council, Summary Record of the Two Hundred and Fifteenth Meeting, 659 .

131. Ibid, 652 .

132. Ibid, 654 .

133. Ibid, 659.

134. Kathleen Renee Cronin-Furman, "60 Years of the Universal Declaration of Human Rights: Towards an Individual Responsibility to Protect," American University International Law Review 25 (2010): 181. 135. Richard N. Gardner, "The Genesis of the Declaration: A Fresh Examination," Pace International Law Review 27 (1999): 39.

136. United Nations, Third Committee, Summary Record of the Hundred and Seventy-Ninth Meeting, UN Doc. A/C.3/SR.179, at 893 (1948). 
the ideal of universality and help the UDHR apply equally to all persons. ${ }^{137}$ Finally, the UDHR arrived at its last hurdle: the Plenary of the United Nations General Assembly.

During the Plenary of the General Assembly meeting on December 9 and 10 of 1948 , Malik, Roosevelt, and Cassin all gave memorable speeches in wholehearted support of the UDHR. Malik paid tribute to the arduous yet meaningful drafting process of the document as well as the able work of many representatives, including Pavlov of the USSR. ${ }^{138} \mathrm{He}$ further concluded that the UDHR would not only promote respect for human rights and fundamental freedoms but also help bring about changes in legal practices across the world. ${ }^{139}$ Roosevelt stressed the importance of the UDHR as the first and foremost declaration of basic principles, articulating a common standard for all nations, a "Magna Carta of all mankind." 140

In response to the consistent amendments forwarded to the meeting by the USSR, Roosevelt also harshly denounced their reluctance to cooperate. ${ }^{141}$ Cassin highlighted that a complete agreement on doctrine was impossible but that an agreement based on ideals could and must be achieved. ${ }^{142}$ He also summarized four fundamental pillars upon which the UDHR rested, including the ideas of personal rights, relationships between all humans, public liberties and fundamental political rights, and economic and social rights. At this point, Cassin affirmed that each of these liberties was equally important. ${ }^{143}$

Again, the Eastern Bloc voiced concerns regarding state sovereignty and other issues related to their unsuccessful amendments. ${ }^{144}$ Thus, on December 10, the Soviet representatives proposed several revisions, which were essentially the same as those that had been defeated in the Third Committee, in a vain attempt to postpone the document's adoption until the following year. ${ }^{145}$ These concerns, however, did not prove irreconcilable. The only change made was the elimination of one article and the placement of the same idea in article two; this text concerned the universal application of the UDHR in trust and non-self-governing territories, primarily colonial territories. ${ }^{146}$ Hence, the total number of articles within the document came to an even thirty.

Finally, around midnight, a roll call vote was issued. A historical moment was thereafter achieved; the Universal Declaration of Human Rights was adopted by the United Nations, with 48 votes to zero plus 8 abstentions (the BSSR, Czechoslovakia, Poland, Saudi Arabia, Ukraine, the Union of South Africa, USSR, and Yugoslavia). ${ }^{147}$

137. United Nations, Third Committee, Summary Record of the Hundred and Sixty-Third Meeting, UN Doc. A/C.3/SR.163, at 742 (1948).

138. United Nations, General Assembly, Verbatim Record of the Hundred and Eightieth Plenary Meeting, UN Doc. A/PV.180, at 857-860 (1948).

139. Ibid, 861.

140. Ibid, 862 .

141. Ibid, 861 .

142. Ibid, 865 .

143. Ibid, 866 .

144. Ibid, 854-857.

145. United Nations, Amendments Proposed by the Union of Soviet Socialist Republics to the Draft Declaration, UN Doc. A/784 (1948).

146. United Nations, United Kingdom, Amendment to Article 3 of the Draft Declaration proposed by the Third Committee, UN Doc. A/778/Rev.1 (1948).

147. United Nations, General Assembly, Verbatim Record of the Hundred and Eighty-Third Plenary Meeting, UN Doc. A/PV.183, at 933 (1948). 


\section{Legal Significance of the UDHR}

"The single most important reference point" for transnational and cross-cultural discussions on human rights and fundamental freedoms, the UDHR, proved to be a groundbreaking document that demonstrated that there could be an effective consensus to assert a commitment to human rights for all of humankind. ${ }^{148}$ That the document was adopted with unanimous approval, that the Eastern Bloc cautiously abstained rather than voting against it, and that of some 1,233 individual votes taken in the Third Committee, 88.08 percent proved affirmative all demonstrate how morally compelling and publicly prevalent the human rights project had become. ${ }^{149}$

Although there was ostensibly general approval of the UDHR, its worth and prospects were interpreted in radically different ways by different parties. ${ }^{150}$ What remains most uncertain is the precise legal significance of the document. For the most part, the architects of the UDHR believed that it provided moral guidelines rather than acting as a legal instrument. The working group considered the convention much more responsible for implementation than the Declaration itself, which was "consequently not legally binding in the strict sense of the term." 151

Shortly after its adoption, Sir Hersch Lauterpacht, probably the best-known international law scholar of the time, struck a sobering tone on the UDHR, stating that "by its nature and by the intention of its parties," it existed outside of state and international

law. ${ }^{152}{ }^{153}$ Many observers agreed with this perspective at the time, arguing that the Declaration was primarily symbolic and that its political and moral importance outweighed its legal significance. ${ }^{154}$ By the general definition of law, legal validity and normativity are required, which essentially ensured that the Declaration was not technically law given the challenge of directly enforcing it. ${ }^{155}$

Despite this contention, it has since been argued that the Declaration does in fact have legal weight. Proponents of this argument contend that the UDHR derives its legal power from two essential sources: its composition as based upon customary international law and its incorporation into national legislations.

The first argument for the document's power is often closely associated with the UDHR's relevance to the UN Charter. René Cassin frequently insisted that the Declaration

148. Mary Ann Glendon, "The Rule of Law in the Universal Declaration of Human Rights," Northwestern Journal of International Human Rights 1 (2004): 19.

149. United Nations, General Assembly, Verbatim Record of the Hundred and Eightieth Plenary Meeting, UN Doc. A/PV.180, at 860 (1948).

150. Gabriel Moran, "Human Rights Need a Human Tradition," CrossCurrents 62, no. 1 (2012): 76.

151. Commission on Human Rights, Draft Report of the Working Group on Implementation, UN Doc. $\mathrm{E} / \mathrm{CN} .4 / 53$, at $2(1947)$.

152. Hersch Lauterpacht, "The Universal Declaration of Human Rights," British Yearbook of International Law 25 (1948): 365-369.

153. Hersch Lauterpacht, International Law and Human Rights (London: Stevens \& Son, 1950), 416-417. 154. Jochen von Bernstorff, "The Changing Fortunes of the Universal Declaration of Human Rights: Genesis and Symbolic Dimensions of the Turn to Rights in International Law," European Journal of International Law 19, no. 5 (2008): 905.

155. Andrei Marmor and Alexander Sarch, "The Nature of Law," in The Stanford Encyclopedia of Philosophy (Fall 2015 Edition), ed. Edward N. Zalta, accessed September 1, 2017, https://plato. stanford.edu/archives/fall2015/entries/lawphil-nature. 
was not "a purely theoretical instrument," but one that may potentially envelop "the binding forces of the provisions of the Charter."156 From this perspective, the document may be understood as an explicit elaboration of the rights granted by the UN Charter, a perspective that supports the understanding of UDHR as a part of treaty law or, more precisely, a codification of customary international law. Initially, this view was held only by a handful of people, including John Humphrey, though it came to be adopted far more broadly over time. ${ }^{157}$

Achievement after achievement following the document's adoption have evidenced that the UDHR is now a benchmark for international legal norms regarding human rights. ${ }^{158}$; 159 The UN General Assembly has frequently cited the Declaration in its resolutions - 75 in total by 1969 - at least once every session. ${ }^{160}$ When battling racial discrimination in South Africa, the General Assembly called for the principles of the UN Charter and UDHR to be taken into consideration. ${ }^{161}$ The UDHR was also invoked by the UN as a moral and political standard against which to consider issues of forced labor, freedom of movement in Eastern Europe, and discrimination in non-self-governing and trust territories. ${ }^{162}$ By 1960, the General Assembly had come to affirm that all states should "observe faithfully and strictly" the language of the Declaration, leading nations to follow the document's guidelines more closely. ${ }^{163}$

In fact, since its final drafting, the UDHR has been reaffirmed on various international stages, including at conferences and within multiple institutions. In 1968, at the first UN International Conference on Human Rights held in Tehran, Iran, the Proclamation of Tehran was issued and later endorsed by the UN Assembly as an "important and timely reaffirmation" of the central doctrines enshrined within the UDHR. ${ }^{164}$ The Proclamation of Tehran stated that the UDHR constituted "a common understanding" as well as "an obligation" for the entire global community concerning the inalienable rights of all mankind, urging faith and action in conformity with the UDHR's provisions. ${ }^{165}$ Later, in 1993, the UN World Congress on Human Rights held in Vienna, Austria, approved the Vienna Declaration and Programme of Action; in drafting this new human rights legislation,

156. United Nations, General Assembly, Verbatim Record of the Hundred and Eightieth Plenary Meeting, 866.

157. John P. Humphrey, Human Rights and United Nations: A Great Adventure (New York: Transnational, 1984), 65.

158. Vasily Tatsiy, "The Universal Declaration of Human Rights: The Worldwide Humanism Manifesto," Law of Ukraine, no. 5-6 (2011): 32.

159. Richard B. Lillich, "The Growing Importance of the Customary International Human Rights Law," Georgia Journal of International and Comparative Law 25 (1996): 1-30.

160. Samuel A. Bleicher, "The Legal Significance of Re-Citation of General Assembly Resolutions," American Journal of International Law 63 (1969): 463.

161. United Nations, Treatment of People of Indian Origin in the Union of South Africa, UN Doc. A/Res. 265(III), OP 1.

162. Egon Schwelb, "Human Rights and the International Community," in The Roots and Growth of the Universal Declaration of Human Rights, ed. Roger Stenson Clark (The Hague: Martinus Nijhoff, 1963), 55. 163. United Nations, Declaration on the Granting of Independence to Colonial Countries, UN Doc. A/Res. 1514(XV), OP 7.

164. United Nations, International Conference on Human Rights, Resolution adopted on the Report of the Third Committee, UN Doc. A/RES/2442(XXIII) (1968).

165. United Nations, Proclamation of Tehran, Final Act of the International Conference on Human Rights, UN Doc. A./CONF.32/41, at 3 (1968). 
representatives observed that the UDHR had been "the basis for the United Nations in making advances in standard settings" of human rights. ${ }^{166}$ This observation was reaffirmed when the newly devised UN Human Rights Council invented the Universal Periodic Review, an innovative peer-review mechanism for monitoring adherence to human rights standards, and established the UDHR as the basis for the review. ${ }^{167}$

The International Court of Justice (ICJ), one of the primary enforcement mechanisms of international conventions, also alluded to the UDHR when assessing the case of the Iran hostage crisis, during which fifty-four US diplomats were held by supporters of the Iranian Revolution for more than a year. The ICJ concluded that, according to the principles of the UDHR, hostage-taking itself constituted wrongdoing. ${ }^{168}$ Earlier, Fouad Ammoun, the Vice-President of ICJ, had remarked that the Declaration could "bind States on the basis of custom" because it "acquired the force of custom through a general practice accepted as law." 169 Indeed, it has been argued by many that the very definition of "rule of law" should include the defense of natural justice personified in the UDHR and other documents. ${ }^{170}$

The second rationale depends upon the reality that international treaties have also been important in terms of the UDHR's enforcement. In 1966, two covenants - the International Covenant on Civil and Political Rights (ICCPR) and the International Covenant on Economic, Social and Cultural Rights (ICESCR) - were adopted and came into effect over the next decade. Evident in the preambles of the ICCPR and ICESCR is the paramount role of the Declaration as a bridge between the human rights provisions in the UN Charter and the two covenants themselves. ${ }^{171}$ Although delayed considerably due to irreconcilable Cold War tensions between the Western and Eastern Blocs, which were also responsible for the division of the covenant into two parts, the ICCPR and ICESCR were still expected to act as binding legal instruments that safeguarded human rights in accordance with the UDHR across nations.

For many, the two covenants were automatically considered superior to and thus more valuable than the UDHR because their legally binding natures seemed more punitive and enforceable. ${ }^{172}$ However, many international law scholars disagreed with this proposition, as both the ICCPR and ICESCR have been accepted by more than three-fourths of UN member states by signature and ratification. Although a signature on a UN covenant merely conveys the willingness of a signatory state to proceed to the treaty-ratifying process, such an action suggests further ratification towards embracing that covenant as a

166. "Vienna Declaration and Programme of Action," World Conference on Human Rights in Vienna, 1993, accessed September 1, 2017, http://www.ohchr.org/EN/ProfessionalInterest/Pages/Vienna.aspx. 167. Noelle Higgins, "Advancing the Rights of Minorities and Indigenous Peoples: Getting UN Attention Via the Universal Periodic Review," Netherland Quarterly of Human Rights 32, no. 4 (2014): 379-407.

168. United States Diplomatic and Consular Staff in Tehran (United States of America v. Iran) Judgment, ICJ Report, at 42 (1980).

169. "Legal Consequences for States of the Continued Presence of South Africa in Namibia (South West Africa) Notwithstanding Security Council Resolution 276 (1970), ICJ Reports, 1971, p. 16," American Journal of International Law 66, no. 1 (1972): 145-183.

170. Carol Wang, "Rule of Law in Afghanistan: Enabling a Constitutional Framework for Local Accountability," Harvard International Law Journal 55, no. 1 (2014): 212-249.

171. Johannes van Aggelen, "The Preamble of the United Nations Declaration of Human Rights," Denver Journal of International Law and Policy 28, no. 2 (2000), 138.

172. Stephen Gardbaum, "Human Rights as International Constitutional Rights," European Journal of International Law 19, no. 4 (2008): 749-768. 
legally binding force in the future. However, the list of parties that have not ratified also includes approximately 30 states for each covenant - for example, the US is not a party to the ICESCR, and China has not ratified the ICCPR. As a result, the covenants' sizes and ranges of influence are limited. ${ }^{173}$

The UDHR reaches a much broader audience than the ICESCR or the ICCPR by utilizing the term "universal," meaning that its provisions apply to every individual and every organ of society on the planet. Furthermore, the relatively vague wording of its provisions foster more flexibility in terms of legal interpretation, in contrast to the precise and detailed language of the covenants. ${ }^{174}$ Moreover, in practice few relevant cases based on the covenants have been submitted to the ICJ, and those that have achieved only limited success, meaning that these two covenants have played a largely idealistic role, similar to that of the Declaration. ${ }^{175}$ Hence, it is not surprising that Charles Malik admitted in 1986, "Wherever the question of human rights has risen throughout the world, the appeal has been far more to the Declaration than to the covenants." ${ }^{176}$ According to the International Law Association, recognition of the UDHR as a primary global human rights standard and source for state legislation throughout the world "distinguishes it from conventional obligation." 177

In addition to the ICCPR and ICESCR, more than 70 conventions on human rights have been established throughout the globe since the adoption of the UDHR; all of these directly or indirectly found inspiration in the original document, and many reference it in their preambles. ${ }^{178}$ The paramount conventions adopted by the UN since the UDHR are: the Convention on the Rights of the Child; the Convention Against Torture and Other Cruel, Inhuman or Degrading Treatment or Punishment; the International Convention on the Elimination of All Forms of Racial Discrimination; and the Convention on the Elimination of All Forms of Discrimination Against Women. These four conventions, along with others, have elaborated rights outlined in the UDHR and specified liberties to which certain groups of people are entitled on an international level.

The principles of human rights embodied in the Declaration have been consistently affirmed in regional treaties, such as the African Charter of Human and Peoples' Rights, which was adopted in 1981 and has been ratified by every state on the African continent. ${ }^{179}$ A more recent example is the Gulf Declaration on Human Rights adopted by the Gulf Cooperation Council in 2014, which epitomizes a regional customary human rights system in the form of reconciliation between complex cultural values and universal principles. ${ }^{180}$

173. Sam McFarland, "The Slow Creation of Humanity," Political Psychology 32, no. 1 (2011): 12.

174. Schabas, The Universal Declaration of Human Rights, vol. 1 (Cambridge: Cambridge University Press, 2013), cxvii.

175. Ibid, cxvi-cxvii.

176. Charles Malik, "1948 - The Drafting of the Universal Declaration of Human Rights," UN Bulletin on Humanitarian Rights 97 (1986).

177. Sandy Ghandhi, "The International Bill of Rights and the European Conventions on Human Rights," Legal Information Management 6 (2006): 284.

178. Tatsiy, "The Universal Declaration of Human Rights," 32.

179. "African Charter of Human Rights and Peoples' Rights," African Commission on Human and Peoples' Rights, 1986, accessed September 1, 2017, http://www.achpr.org/instruments/achpr/.

180. Khalifa A. Alfadhel, "The GCC Human Rights Declaration: An Instrumentation of Cultural Relativism," Arab Law Quarterly 31 (2017): 89-98. 
Between 1988 and 1997, the percentage of cases accepting the UDHR as a precedent for international law almost doubled, to 50 percent. ${ }^{181}$ In today's context, the Declaration serves as a milestone in the development of many key legal concepts (for example, the injustice of excluding persons from international refugee protection based on criminal conduct) that are understood and applied under the auspices of other international conventions. ${ }^{182}$ The norms expressed by the UDHR as well as the ways that they are contextualized have also provided a benchmark for evaluating controversial policies, such as migration control and refugee protection. ${ }^{183}$

The second means by which the UDHR has become a legal document is through its incorporation into national legislations. Initially, the document's architects expected jurisprudence at the national level to be "the best and surest legal means" for ensuring human rights protection, yet such usage did not begin with the adoption of the UDHR itself. ${ }^{184}$ Since its inception, multiple national governments have agreed to shoulder the final responsibility for defending human rights within their territories. Hence, examining the impact of the Declaration on law at a national level is of vital importance in any effort to assess its practical legal significance. At least 25 states have explicitly referred to the UDHR in their constitutions, many of which are African states that have emerged from under colonial rule, and approximately 80 states have constitutionally recognized the norms of international law, which implicitly renders legal support for the Declaration. ${ }^{185}$ There is also strong empirical basis for the argument that the inclusion of rights in the UDHR boosts the likelihood of its incorporation in a national constitution by more than fifty percent, which illuminates the UDHR's power to shape domestic rights structures and increase actual rights compliance. ${ }^{186}$ Furthermore, despite criticisms that the UDHR's inherent ambiguities are responsible for its inconsistent efficacy, it has been explicitly cited in at least 166 national cases as the rationale for domestic judicial decisions or opinions, so it clearly serves as a guide for legal judgments worldwide. ${ }^{187} ;{ }^{188}$

However, it should also be noted that the Declaration and the abundance of conventions and resolutions that followed from it all confront one basic failure: they have not been put into practice by a substantial number of UN member states, more than half of which are dominated by dictatorial regimes whose constitutions, ironically, exhibit greater similarity to the UDHR than do those of common law countries, but where these legislative guidelines

181. Tai-Heng Cheng, "The Universal Declaration of Human Rights at Sixty: Is It Still Rights for the United States?", Cornell International Law Journal 41 (2008): 251.

182. Sibylle Kapferer, "Article 14(2) of the Universal Declaration of Human Rights and Exclusion from International Refugee Protection," Refugee Survey Quarterly 27, no. 3, (2008): 75.

183. Thomas Gammeltoft-Hansen and Hans Gammeltoft-Hansen, "The Right to Seek-Revisited. On the UN Human Rights Declaration Article 14 and Access to Asylum Procedures in the EU," European Journal of Migration and Law 10 (2008): 439-459.

184. Glendon, "The Rule of Law," 12.

185. Hurst Hannum, "The Status of the Universal Declaration of Human Rights in National and International Law," Georgia Journal of International and Comparative Law 25 (1995): 287.

186. Zachary Elkins, Tom Ginsburg, Beth Simmons, "Getting to Rights: Treaty Ratification, Constitutional Convergence, and Human Rights Practice," Harvard International Law Journal 54, no. 1 (2013): 61-95.

187. Tai-Heng Cheng, "The Universal Declartaion of Human Rights at Sixty: Is It Still Right for United States," Cornell International Law Journal 41, no. 2 (2008): 251-305.

188. Hurst Hannum, "The Status of the Universal Declaration of Human Rights in National and International Law," 287. 
have remained largely rhetorical. ${ }^{189} ;{ }^{190}$ Even in democratic regimes, international human rights laws fail to restrain executive action when rationales regarding national security and military necessity are offered. ${ }^{191}$ Nonetheless, the Declaration, through its role as international customary law and its incorporation into domestic legal practice, has derived its legitimacy and served to positively shape the current international human rights system. Thus, it, "perhaps, is law in the making." 192

189. Jacob Dolinger, "The Failure of the Universal Declaration of Human Rights." University of Miami Inter-American Law Review 47 (2016): 191.

190. David S. Law and Mila Versteeg, "The Declining Influence of the United States Constitution," New York University Law Review 87 (2012): 762-858.

191. Natsu Taylor Saito, "Justice Held Hostage: U.S. Disregard for International Law in the World War II Internment of Japanese Peruvian-Case Study," Boston College Third World Law Journal 19, no. 1 (1998): 275.

192. Egon Schwelb, "The Influence of the Universal Declaration of Human Rights on International and National Law," Proceedings of the American Society of International Law 53 (1959): 229. 


\section{Moral Significance of the UDHR}

Originally, the focus on the moral value and authority of the UDHR was echoed and supported by the document's architects. Roosevelt in particular was confident in its efficacy, partly due to her perception of the way the Declaration of Independence had evolved and acted as a guide for conduct throughout the US. ${ }^{193}$ However, the moral importance of the UDHR is bound up in its legal significance; the document continues to evolve and grow in strength on the merit of the ideologies it contains. Inevitably, the role of global-scale morality is tied to the various changes in the geopolitical landscape.

In terms of acting as a standard for ethical behavior, the Declaration is widely viewed as the guiding source for contemporary human rights activism, whose functional organs are primarily NGOs. ${ }^{194.195}$ The moral spirit of the Declaration, sometimes referred to as a "worldwide secular religion," has operationalized the responsibility to protect (R2P) norm, which requires that state parties protect not only their own citizens but also persons within other countries' borders who may be harmed by their own governments. ${ }^{196}$

The nongovernmental human rights movement, which predominantly emerged in the 1970s, has been the driving force for application of human rights protections worldwide. ${ }^{197}$ The best-known NGO dedicated to human rights may be Amnesty International, which was founded in 1961 and has received the Nobel Peace Prize for its work. This organization has united 7 million people in more than 150 countries and territories and is committed to ending human rights abuses worldwide through research, lobbying, and other global campaigns.

In conjunction with governmental and international institutions, humanitarian NGOs such as Amnesty International and Human Rights Watch have successfully redefined policy to remedy human rights abuses by utilizing what is referred to as the "shaming-and-naming strategy." 198 This tactic rests upon the moral duty fostered by the UDHR that the entire international community must not stand by any government that abuses the human rights of its citizens. ${ }^{199}$ By actively using popular media to proliferate their campaigns, humanitarian NGOs provoke moral outrage and mobilize disgrace as a means of causing social sanctions and enforcing compliance with human rights commitments. For example, in the case of the abuses at the US-run Abu Ghraib prison in Iraq, a shaming campaign led by Amnesty International led to remedial action by the US government. ${ }^{200}$

193. Glendon, "The Rule of Law," 11.

194. Aryeh Neier, The International Human Rights Movement: A History (Princeton: Princeton University Press, 2012), 158.

195. Makau Mutua, Human Rights NGOs in East Africa: Political and Normative Tensions (Philadelphia: University of Pennsylvania Press, 2009), 164.

196. Elie Wiesel, "Voices: A Tribute to Human Rights," in The Universal Declaration of Human Rights Fifty Years and Beyond, ed. Yael Danieli (Amityville: Baywood, 1999).

197. Dilys M. Hill, "Rights and Their Realisation," in Economic, Social, and Cultural Rights: Progress and Achievement, ed. Ralph Beddard and Dilys M. Hill (New York: Palgrave Macmillan, 1992), 7.

198. Louis Henkin, "Human Rights and State Sovereignty." Georgia Journal of International and Comparative Law 25, no. 31 (1995): 31-45.

199. Kathleen Renee Cronin-Furman, "60 Years of the Universal Declaration of Human Rights: Towards an Individual Responsibility to Protect," American University International Law Review 25 (2010): 184. 200. Sandeep Gopalan, "Alternative Sanctions and Social Norms in International Law: The Case of Abu Ghraib," Michigan State Law Review (2007): 786. 
Indeed, recent studies have provided quantitative evidence from around the globe supporting the "conditional importance" of humanitarian NGOs' shaming tactics in improving human rights in targeted states, particularly in reducing the likelihood and severity of one-sided government killings of the sort seen in genocides and politicides. ${ }^{201} ;{ }^{202}$; ${ }^{203}$ The effects of this strategy are conditional, however; in some cases, ambivalent outcomes are produced due to ineffective approaches by NGOs, uneven capacities for targeted states to reform, regime types, and other reasons. ${ }^{204},{ }^{205}$ Subsequent empirical analyses show that naming and shaming may indirectly influence government behavior not only by creating international pressure but also by shaping domestic public opinion. ${ }^{206}$

In addition to NGOs, multinational corporations (MNCs) have been motivated to shoulder human rights as their corporate social responsibilities, albeit with blurred lines that resist clear classification into legal or ethical categories. ${ }^{207}$ The "shaming-and-naming strategy" is effective in diminishing the amount of investment from MNCs to targeted states, thereby imposing substantial economic costs to the states. ${ }^{208}$ The practicability of the shaming-and-naming strategy indicates that the moral imperatives of the Declaration are not merely substitutes for legal enforcement but might offer an equal, and sometimes even more powerful, tool for battling human rights abuses.

The UDHR has also proven to be an essential device for global politics by offering education and inspiring various political and social movements across the world. In the two decades after WWII and among predominantly Asian, African, and Arab states, the promise of universal human rights has delegitimized the practice of colonialism and offered moral grounds on which such persons may demand the liberty of self-determination, thereby contributing to the proliferation of newly independent states. ${ }^{209}$ For example, Nnamdi Azikiwe, a leading figure of modern nationalists in Nigeria, persistently referred to the UDHR when criticizing the denial of fundamental human rights to many African persons and describing his vision for a democratic system for Nigeria. As a devotee to the UDHR, Azikiwe hopes to integrate human rights into the system of governance in Nigeria and has even outlined a Pan-African union based on existing conventions. ${ }^{210}$

201. Amanda M. Murdie and David R. Davis, "Shaming and Blaming: Using Events Data to Assess the Impact of Human Rights INGOs," International Studies Quarterly 56 (2012): 1.

202. Matthew Krain, "J'accuse! Does Naming and Shaming Perpetrators Reduce the Severity of Genocides or Politicides?", International Studies Quarterly 56, no. 3 (2012): 574-589.

203. Jacqueline H. R. DeMeritt, "International Organizations and Government Killing: Does Naming and Shaming Save Lives?", International Interactions 38, no. 5 (2012): 597-621.

204. Pascal Vennesson, "War Under Transnational Surveillance: Framing Ambiguity and the Politics of Shame," Review of International Studies 40 (2014): 25-51.

205. Cullen S. Hendrix and Wendy H. Wong, "What is the Pen Truly Mighty? Regime Type and the Efficacy of Naming and Shaming in Curbing Human Rights Abuses," British Journal of Political Science 43 , no. 3 (2013): 651-672.

206. Jacob Ausderan, "How Naming and Shaming Affects Human Rights Perceptions in the Shamed Country," Journal of Peace Research 51, no. 1 (2014): 93.

207. Ann Elizabeth Mayer, "Human Rights as a Dimension of CSR: The Blurred Lines Between Legal and Non-Legal Categories," Journal of Business Ethnics 88 (2009): 561-577.

208. Colin M. Barry and K. Chad Clay, "Avoiding the Spotlight: Human Rights Shaming and Foreign Direct Investment," International Studies Quarterly 57, no. 3 (2013): 532-544.

209. Christian Reus-Smit, "Human Rights and the Social Construction of Sovereignty," Review of International Studies 27 (2001): 520.

210. Jan Eckel, "Human Rights and Decolonization: New Perspectives and Open Questions," Humanity: 
Other figures, such as Julius Nyerere of Tanzania and Kwame Nkrumah of Ghana, have also explicitly invoked the human rights framework, although their interpretations have varied and have mostly served as a symbolic means of confronting the dominance of First World nations. ${ }^{211}$ As Nelson Mandela, a leading anti-apartheid activist in South Africa, once said, "The simple and noble words of the Universal Declaration were a sudden ray of hope at our darkest moments." 212

However, although the language of the UDHR gives anticolonial movements tremendous moral support, the document is essentially neutral with regard to civil wars and does not automatically offer legitimacy to any one government. Instead, triumphant movements for self-determination produce retroactive legitimacy, whether by drawing upon the UDHR or by forming their own ideologies. ${ }^{213}$

The moral strengths embedded in the Declaration also transformed the political landscape of the Cold War. By injecting human rights into the diplomacy of détente to relieve tensions between the Eastern and Western Blocs, the Conference on Security and Cooperation of Europe negotiated the Helsinki Final Act in 1975 and explicitly demanded that participating states conform to the guidelines of the UDHR. Far from a legally binding agreement, the Helsinki Final Act was a Declaration of intention with only moral and political obligations. ${ }^{214}$ Nevertheless, based on an ethical commitment spurred by human rights activism, a transnational network was developed that pressed Soviet leaders to improve conditions and even helped to facilitate the end of the Cold War. ${ }^{215}$

The neoconservative human rights movement led by the US gained prominence in the 1970s and 1980s. Distinct from the liberal human rights groups that developed earlier, it redefined political rights in article 21 of the Declaration as referring to democratic rights, in order to justify combatting the rise of communism in Latin America. ${ }^{216}$ This approach has since been criticized for "[fracturing] the human rights community." 217 Perhaps this is because, although human rights are closely associated with politics, they are always expected to be a form of morality that is inherently idealistic, principled, purposive - in some ways, Kantian - and therefore do not conform to or explicitly oppose any one political party in the manipulation of powers. ${ }^{218}{ }^{219}$

The rise of the developing world through the process of decolonization, the relieving of Cold War tensions through détente, and the liberal foreign policy espoused by the US

An International Journal of Human Rights, Humanitarianism, and Development 1, no. 1 (2010): 116. 211. Ibid.

212. Mary Robinson, "The Universal Declaration of Human Rights: A Living Document," Australian Journal of International Affairs 52, no. 2 (1998).

213. Brad Simpson, "The Biafran Secession and the Limits of Self-determination," Journal of Genocide Research 16, no. 2-3 (2014): 337-354.

214. Sarah B. Snyder, Human Rights Activism and the End of the Cold War: A Transnational History of the Helsinki Network (New York: Cambridge University Press, 2011), 5.

215. Ibid, 1-3.

216. Mara Elizabeth Sankey, "Promoting Democracy? The Role of Transnational Non-State Actors in Inter-American Relations 1980-1993" (PhD diss., University College London, 2016), 1-297.

217. Ibid.

218. Devin O. Pendas, "Towards a New Politics? On Recent Historiography of Human Rights," Contemporary European History 21, no. 1 (2012): 95-111.

219. Luke Maclnnis, "Agency and Attitude: Kant's Purposive Conception of Human Rights," Philosophy and Social Criticism 42, no. 3 (2016): 289-319. 
following the Vietnam War were all catalysts for the explosive era of human rights activism in the 1970s. ${ }^{220}$ The UDHR has afforded human dignity a prominent place in geopolitics, which philosophically explains why all persons are born in possession of inalienable human rights and why protection of these liberties matters. ${ }^{221}$ Over time, this focus on morality has led to intensified appeals that cannot be separated from the UDHR's legal relevance because they create "a crystalized consensus of state practice" and make the Declaration part of customary international law. ${ }^{222}$ Indeed, the role of morality in the UDHR may be ambiguous because the detailed contents of dignity sometimes vary with regard to a given community's particular social, religious, and traditional values. ${ }^{223}$ However, by identifying a consensus around the general notion of the inner worth of human beings, the document can capture the emotional energy (which is more important than pure rationality) that appreciably characterized 1970s activism and that may make the Declaration's purpose even more meaningful in years to come. ${ }^{224}$

Perhaps even more significantly, the focus on dignity within the UDHR has allowed states to embrace multiple interpretations, thereby enabling their potential to develop additional and even more accessible rights. ${ }^{225}$ This reality is particularly evident in light of the recent proliferation of human rights, especially economic, social, and cultural liberties, as a potential response to the challenges posed by the contemporary era, such as the process of globalization. ${ }^{226}$

The human rights language within the Declaration has even penetrated the global commerce association, the World Trade Organization (WTO), persuading policymakers to ensure that the rules for international systems of trade are compatible with human rights, particularly those relating to labor. ${ }^{227}$ To address increased transnational communication, the public right to information clause within the UDHR has been used to support the adoption of global freedom of information legislation. ${ }^{228}$ Moreover, to safeguard endangered cultures, the non-discrimination principle within the Declaration has been invoked as grounds for the protection of linguistic diversity. ${ }^{229}$

Following the vigorous trend of social revolution, LGBTQI (lesbians, gay, bisexual, transgender, queer, and intersex) groups have also found grounds on which to campaign for

220. Samuel Moyn, Human Rights and the Uses of History (New York and London: Verso, 2014), 164. 221. Charles R. Beitz, "Human Dignity in the Theory of Human Rights: Nothing but a Phrase?" Philosophy ES Public Affairs 41, no. 3 (2013): 260-290.

222. Rex D. Glensy, "The Right to Dignity," Columbia Human Rights Law Review 43 (2011): 103.

223. Marcio Ricardo Staffen, "The Legal Development of the Notion of Human Dignity in the Constitutional Jurisprudence," Revista Brasileira de Direito 12, no. 2 (2016): 108-126.

224. Roland Burke, "Flat Effect? Revisiting Emotions in the Historiography of Human Rights," Journal of Human Rights 16, no. 2 (2015): 123-141.

225. Adrienne Anderson, "On Dignity and Whether the Universal Declaration of Human Rights Remains a Place of Refuge After 60 Years," American University International Law Review 25, no. 1 (2009): 142. 226. Sumner B. Twiss, "History, Human Rights, and Globalization," Journal of Religious Ethics 32, no. 1 (2004): 39-70.

227. Susan Ariel Aaronson, "Sleeping in Slowly: How Human Rights Concerns Are Penetrating the WTO," World Trade Review 6 (2007): 413-449.

228. Jeannie E. Relly, "Freedom of Information Laws and Global Diffusion: Testing Roger's Model." Journalism \& Mass Communication Quarterly 89, no. 3 (2012): 431-457.

229. Bruno De Witte, "The Protection of Linguistic Diversity Through Fundamental Rights," European University Institute (1985): 621. 
their rights by employing language from the Declaration regarding the rights to families, marriage, and equality between sexes. ${ }^{230}$ The universal character of human rights already condemns discrimination, harassment, and violence against certain populations due to various characteristics; thus, such groups merely extend these rationales to their own contexts, including sexual orientation and gender identities. Specifically, the equality, human dignity, and nondiscrimination clauses within the UDHR, along with language pertaining to the rights to marriage and family integrity and noninterference with private life, have not only been interpreted to protect the interests of European transgender communities against forced sterilization and mandatory divorce laws, but have also been applied to challenge anti-gay propaganda in Russia. ${ }^{231.232}$

Furthermore, the Declaration is often understood as a key document that informs the World Health Organization (WHO) in creating their human rights criteria for mental health legislation, indirectly inspiring laws in Ireland in 2001 and the UK in $2007 .{ }^{233}$ In general, the expanded applications of human rights in the global governance of health can contribute to an improvement in human rights, particularly for those with mental disabilities. ${ }^{234}$ The UDHR, along with the philosophical traditions that preceded it and the international laws that followed it, has established a natural right to health care, obligating states to provide relevant fair and just implementation. ${ }^{235}$ The clause regarding rights to housing, health care, and adequate food in the Declaration has also proven foundational for alleviating urban poverty and slums. ${ }^{236}$ Similarly, the right to decent minimum water rations to meet drinking, sanitation, and other basic needs has recently been conceptualized and encouraged. ${ }^{237}$

In the developing biological technology (biotech) industry, the unstated reliance on "nature" to derive inherence, inalienability, and universality for human rights within the Declaration has led to the theory of the biological foundation of human rights and the discourse of bioethical inquiry. ${ }^{238}$ In reference to intellectual property issues, the right to "cultural life" and the right to "share in scientific advancement and its benefit" in article 27 of the UDHR are examined to provide the meaning of cooperative justice in an innovation

230. Nick J. Mule, Maryam Khan, and Cameron McKenzie, "The Growing Presence of LGBTQIs at the UN: Arguments and Counter-arguments," International Social Work (2017): 5.

231. Rebecca Lee, "Forced Sterilization and Mandatory Divorce: How A Majority of Council of Europe Member States' Laws Regarding Gender Identity Violate the Internationally and Regionally Established Human Rights of Trans People," Berkeley International Journal of Law 33 (2015): 128.

232. Stephan Polsdofer, "Pride and Prejudiced: Russia's Anti-Gay Propaganda Law Violates the European Conventions on Human Rights," American University International Law Review 29, no. 5 (2014): 1069-1096. 233. Brendan Desmond Kelly, "Human Rights Protection for the Mentally Ill though Mental Health Law in England and Ireland," (PhD diss., University of Leicester, 2012): 1-345.

234. Lance Gable, "The Proliferation of Human Rights in Global Health Governance," Journal of Law, Medicine \& Ethics 3, no. 1 (2009): 534-544.

235. Jason T. Eberl, Eleanor D. Kinney, and Matthew J. Williams, "Foundation for A Natural Right to Health Care," Journal of Medicine and Philosophy 36 (2011): 537-557.

236. James C.N. Paul and Roktim Kaushik, "Urban Poverty and the Right to a Decent Habitat as Established by International Human Rights Law," Rutgers Law Review 63, no. 3 (2011): 905-939.

237. The Rt Hon Lady Justice Arden, "Water for All? Developing a Human Right to Water in National and International Law," International Law and Comparative Law Quarterly 65, no. 4 (2016): 771-789.

238. David Keane, "Survival of the Fairest? Evolution and the Geneticization of Rights," Oxford Journal of Legal Studies 30, no. 3 (2010): 467-494. 
incentive system. ${ }^{239}$ In reaction to the environmental crisis, activists often cite article 3 of the UDHR, noting that "everyone has the right to life, liberty and security of person." This article became one justification for a 2005 petition against the US by indigenous Inuit people, which framed climate change as infringing upon their enjoyment of the right to life. ${ }^{240}$ In 2010, a similar incorporation of human rights into climate issues first appeared in a UN agreement, formally broadening the scope of negotiation and implementation. ${ }^{241}$

With prominent legal and moral significance, the UDHR has become a living document. Although its relevance has never faltered in the decades since its adoption, interpretations of the text have adapted to the changing world. The salience of human rights, which since the 1970s has emerged in political, social, and intellectual spheres across the globe, is sometimes considered a "hazy expression of hope" for the perseverance of basic values in a world that is full of great uncertainties and possible turbulence. ${ }^{242}$ In this sense, the Declaration has proven to be a meaningful guide.

239. Cristian Timmermann, "Sharing in or Benefiting from Scientific Advancement?", Science and Engineering Ethics 20 (2014): 111-133.

240. Timo Koivurova, Sébastien Duyck, and Leena Heinämäki, "Climate Changes and Human Rights," in Climate Change and the Law, Ius Gentium: Comparative, ed. E. J. Hollo (New York: Springer, 2013), 292. 241. Linda Wallbott and Andrea Schapper, "Negotiating by Own Standards? The Use and Validity of Human Rights Norms in UN Climate Negotiations," International Environmental Agreement: Politics, Law, and Economics 17 (2017): 209.

242. Samuel Moyn, "Substance, Scale, and Salience: The Recent Historiography of Human Rights," The Annual Review of Law and Social Science 8 (2012): 136. 


\section{Challenges, Criticism, and Counterargument}

\subsection{Enforceability}

Despite the declaration's legal and moral imperatives, its enforceability has always been challenged. After all, along with the other human rights agreements and treaties, the UDHR has failed to satisfy the entirety of the promises made due to its inherently idealistic character. Excluded are hundreds of millions of people who live in conditions of injustice, inequality, insecurity, and abuses by dictatorial leadership and who are unable to enjoy their full rights. This global assault on human rights, however, is not the fault of the declaration itself but results from the absence of an effective, collective enforcement mechanism at both the national and international levels. ${ }^{243}$

It is an undeniable fact that many international agreements are practically unenforceable and remain essentially aspirational until states become more willing to soften their stance regarding sovereignty. ${ }^{244}$ State sovereignty has formed the pillar of the international system since the drafting of the UDHR and remains so sixty years later. The claim is that sovereignty, the unregulated exercise of self-governing, is in itself a basic human right. ${ }^{245}$ This view is particularly popular among Asian states. National sovereignty, territorial integrity, and non-interference policies have consistently been hallmarks of the Association of Southeast Asian Nations' (ASEAN) approach to human rights, as evidenced in the 2009 ASEAN Human Rights Declaration. ${ }^{246}$

Other voices have rejected the notion of absolute sovereignty, stating that international relations should be characterized not only by equality and independence but also by interdependence. ${ }^{247}$ If the UDHR is viewed as a codification of international law, it is, by its very nature, nothing more than a social contract similar to the constitution of a democratic government. In this regard, the declaration itself allows for the free exercise of self-governance, albeit on the international level. There has been increasing recognition of

individuals, rather than merely states, as subjects of international law. ${ }^{248}$ Nevertheless, when drafted, both the UN Charter and the declaration firmly denounced any infringement upon state sovereignty. Whether such a notion has or should evolve remains at the center of controversy to this day.

One concern about absolute state sovereignty involves holding individuals in power accountable for human rights abuses, such as in the cases of the former Yugoslavia and Rwanda. The war crimes in these two countries were addressed by temporary international criminal tribunals that mirrored those that occurred in Nuremberg and Tokyo in 1946 but

243. "The Human Rights Trend of the Last 60 Years," Amnesty International, 2008, accessed September 1, 2017, https://www. amnesty.org/en/documents/act30/025/2008/en/.

244. Andrew Truitt, "Ancient Roots and Modern Offshoots: The Development of International Human Rights," Regents Journal of International Law 7 (2009): 220.

245. Robert Araujo, "Sovereignty, Human Rights, and Self-Determination: The Meaning of International Law." Fordham International Law Journal 24 (2001): 1477-1478

246. Attilio Pisano, "Human Rights and Sovereignty in the ASEAN Path Towards a Human Rights Declaration," Human Rights Review 15, no. 4 (2014): 391.

247. Johan D. van der Vyver, "A Reality Check: The Binding Force of Economic and Social Rights Listed in the Universal Declaration of Human Rights," Hamline Journal of Public Law and Policy 30 (2008): 153. 248. Rosalyn Higgins, "Conceptual Thinking About the Individual in International Law," British Journal of International Studies 4, no. 1 (1978): 1-19. 
that failed to impugn the various state leaders. ${ }^{249}$ In 2002, the International Criminal Court (ICC) was established, the world's first permanent international judicial institution. The ICC currently oversees trials involving four types of crimes (i.e., genocide, crimes against humanity, war crimes, and crimes of aggression) and provides certain accountabilities for the worst human rights abuses. ${ }^{250}$ In Prosecutor v. Omar Hassan Ahmad al-Bashir, for example, the ICC was able not only to address the humanitarian crisis in Darfur but also to challenge international immunity for heads of state. ${ }^{251}$ Thus, in some ways, the court acts to prevent the worst human rights violations possible from occurring under the umbrella of absolute sovereignty.

The irony between state sovereignty and internationalism may be addressed by a new dual theory of human rights. Under this model, coercive domestic forces may provide instruments "to ensure people are treated like human beings," whereas international force can only intervene when people are denied their fundamental human rights. ${ }^{252}$ Like a compromise, the dual theory not only agrees with the UN Charter and the framers of the UDHR in arguing that essential human rights are matters of domestic sovereignty but also affirms the conditional role of internationalism in the form of cooperation and intervention. ${ }^{253}$ This theory is supported by the feasibility of fulfilling economic and social rights for children in developing states through both domestic resource mobilization and international assistance. ${ }^{254}$ It may be promising in addressing pressing issues in Sub-Saharan Africa, such as multifaceted poverty and insufficient access to social and economic services. NGOs may be able to offer international assistance by empowering local communities with the integration of native cultural values and identification. ${ }^{255}$ It may also be effective when combining both international pressure and national mechanisms to remedy systemic violence toward women and other vulnerable groups. ${ }^{256}$ Nonetheless, the condition and scope of global intervention remain the focus of debate.

The enforceability of the declaration has also been challenged by skepticism. Many perceive the UDHR as a mere symbol of unity in an increasingly fragmented and controversial political environment. ${ }^{257}$ From this perspective, the declaration is simply a collection of utopian ideals facing the realism of geopolitics and international relations that are essentially based in self-interest rather than principles. This view is partly supported

249. Peter R. Baehr, "Controversies in the Current International Human Rights Debate," Human Rights Review 2, no. 1 (2000): 18.

250. Fatou Bensouda, "Forward," in The Law and Practice of the International Criminal Court, ed. Carsten Stahn (Oxford: Oxford University Press, 2015), xii.

251. Ramona Pedretti, Immunity of Heads of State and State Officials for International Crimes (Leiden: Martinus Nijhoff, 2014), 202-205.

252. Marcus Arvan, "A Better Dual Theory of Human Rights," The Philosophical Forum 45 (2014): 17-47. 253. Monteiro, Ethics of Human Rights, 143.

254. Michael Nyongesa Wabwile, "Legal Protection of Social and Economic Rights of Children in Developing Countries: Reassessing International Cooperation and Responsibility," PhD diss., University of Leicester, 2009.

255. John F. Jones and James Herbert Williams, "Summary and Conclusion: A View from the Bridge," in Conflict and Human Security in Africa: Kenya in Perspective, ed. Asfaw Kumssa, John F. Jones, and James Herbert Williams (New York: Palgrave Macmillan, 2011), 197.

256. Bonita Meyersfeld, "A Theory of Domestic Violence in International Law," JSD Thesis, Yale Law School (2016), 334 .

257. Bernstorff, "The Changing Fortunes," 924. 
by the unjust double standards applied by some of the permanent members in the UN Security Council when referring humanitarian crimes to the ICC, especially through their use of the veto power to protect allies. ${ }^{258}$ These double standards are also evident in the practice of exceptionalism by global powers such as the US in their noncompliance with human rights law, although the fragmentation of political powers has been one convincing rationale for this occurrence as well. ${ }^{259}$

Moreover, no consensus has been reached regarding which techniques beyond legal ramifications may be effectively employed to protect human rights internationally. Economic sanctions may hurt at-risk populations indiscriminately, military interventions may cause mass destruction, and diplomatic condemnation may lead to further politicization and denigration of human rights. ${ }^{260}$ The notion of justice itself may also be constantly challenged; the notion of a "just war" - for example, the war on terror in the post-September 11 era - has also been denounced as a rhetorical cover for neoliberal imperialism. ${ }^{261}$ Similar narratives occur when military intervention of more developed states occurs in failed or less powerful states to resolve conflicts and restore peace, making justice difficult to assess. ${ }^{262}$ From this perspective, the declaration, and perhaps the international legal system as a whole, offers little guidance on judicial procedure and affords too much discretion on the part of individual states, thereby threatening the integration of accurate and relevant scientific information into judicial resolution. ${ }^{263}$

Admittedly, the UDHR is an idealistic document, making it extremely difficult, if not impossible, for it to fulfill all its promises for both sovereignty and political consideration. However, it is exactly the inspiring force of idealism within the declaration that makes it morally significant. Furthermore, the document is not purely based in utopianism but also in "a realism that demand $[\mathrm{s}]$ possible" change and develops mechanisms to obtain legal restitution. ${ }^{264}$

\subsection{Cultural Relativism}

Even more threatening to the strength of the UDHR is the challenge to the notion of universalism. Under the philosophy of cultural relativism, the concept of human rights is

258. Richard Dicker, "International Criminal Court and Double Standards of International Justice," in The Law and Practice of the International Criminal Court, ed. Carsten Stahn (Oxford: Oxford University Press, 2015), 3-12.

259. Anna Unger, Stuart Wallace, and Tamas Dezso Ziegler, "The Role of Human Rights in EU-US Bilateral Relations," FRAME Deliverable 6, no. 5 (2016): 22.

260. Matthew Lippman, "Human Rights Revisited: The Protection of Human Rights under the International Covenant on Civil and Political Rights," Netherland International Law Review 26 (1979): 276.

261. Mark Evans, "Just War, Democracy, Democratic Peace," European Journal of Political Theory 11, no. 2 (2011): 191.

262. John Yoo, "Fixing Failed States," California Law Review 99 (2011): 150.

263. Remi Moncel, "Dangerous Experiments: Scientific Integrity in International Environment Adjudications after the ICJ's Decision in Whaling in the Antarctic," Ecology Law Quarterly 42, no. 2 (2015): 305.

264. Justin Zaremby, "On the Uses and Disadvantages of History for Human Rights Law: Reading Samuel Moyn's The Last Utopia: Human Rights in History," Yale Human Rights and Development Journal 15 (2012): 161 . 
thought to be, like other beliefs and norms, solely the product of socialization and power and to vary from culture to culture and from time to time. Hence, universalism is deemed inherently invalid in this view. Indeed, cultural relativism seems appealing because it involves equal respect for all cultures and value systems. ${ }^{265}$

The quarrels during the drafting process - most notably the one that occurred between the Western and Eastern Blocs regarding political and civil rights versus economic, social, and cultural rights - proved that different societies emphasize different rights. Even in the 1980s, it was a common understanding that in the US, human rights should only include life, liberty, and property, which were best satisfied by a free market and without state intervention. ${ }^{266}$ Later, some Third World intellectuals introduced another perspective on human rights that focused primarily on self-determination and economic development, arguing that the UDHR was a tool for Western cultural imperialism. ${ }^{267}$ In the eyes of non-Westerners, societies should be duty-driven rather than rights-based, focused on collectivity rather than individuality, and, finally, adhering to restorative rather than legal methods. ${ }^{268}$ Such societies argue that the declaration does not reflect their values but Western ones; only 6 of the UDHR's 25 paragraphs mention collective rights. Furthermore, the declaration was initially drafted only by several individuals and formulated and adopted by only 56 states prior to the era of decolonization. ${ }^{269}$ Thus, despite some involvement from non-Western states in the drafting and debating process as well as the incorporation of some Eastern ideas, many believe that the declaration's Western origins are "underpinning" the declaration. ${ }^{270} ;{ }^{271}$

Cultural relativism presents many complicated issues, one of which is Islamic fundamentalism, such as in the aforementioned case of Iran. With the overthrow of the more secular government of Iran in 1979, Islamic fundamentalism has led the country to become a religious state wherein strict Sharia Law (laws based upon Islam and, particularly the Quran and the Hadith) is enforced. Under such systems, conflicts such as gender inequality and religious persecution emerge between Islamic traditions and the human rights ideals in the declaration. ${ }^{272}$ In 2009, Iran issued a national report to the UN General Assembly declaring the nation's adherence to Sharia law, asking that UN member states respect

265. Michal Freeman, "Universalism of Human Rights and Cultural Relativism," in Routledge Handbook of International Human Rights Law, ed. Scott Sheeran and Sir Nigel Rodley (New York: Routledge, 2013), 49.

266. Greg Grandin, "The Liberal Traditions in the Americas: Rights, Sovereignty, and the Origins of Liberal Multilateralism," American Historical Review 117, no. 1 (2012): 90.

267. Amy J. McMaster, "Human Rights at the Crossroads: When East Meets West." Vermont Law Review 29 (2004): 127.

268. Bonny Ibhawoh, "Defining Persecution and Protection: The Cultural Relativism Debate and the Rights of Refugees," in Problems of Protection: The UNHCR, Refugees, and Human Rights, ed. Niklaus Steiner, Mark Gibney, and Gil Loescher (New York and London: Routledge, 2003), 61-75.

269. Christian Tomuschat, Human Rights Between Idealism and Realism (Oxford: Oxford University Press, Oxford, 2003), 63.

270. Aristoteles Constantinides, "Questioning the Universal Relevance of the Universal Declaration of Human Rights," Harvard Human Rights Journal 15 (2000): 101-125.

271. Harold K. Jacobson, "Structuring the Global System: American Contributions to International Organization," The Annals of the American Academy 428 (1976): 87.

272. Heiner Bielefeldt, "Western Versus Islamic Human Rights Conceptions?: A Critique of Cultural Essentialism in Discussion of Human Rights," Political Theory 28, no. 1 (2000): 103. 
cultural diversity, and rejecting pressures from other nations to adopt "Western standards of human rights." 273 Today, Iranian women still face discrimination related to issues of marriage, education, employment, and legal proceedings. ${ }^{274}$ Fundamentalist movements are not exclusive to Iran or Islam but can be both religious and secular in nature and often form the main basis for opposition to cultural homogenization in an era of cosmopolitanism. ${ }^{275}$

As a result, many philosophers offer counterarguments to the concept of cultural relativism. First, cultural relativism itself involves a logical inconsistency because it assumes that a qualified sense of right and wrong exists in different cultures while judging interference from other cultures as wrong in an absolute sense. ${ }^{276}$ In other words, the theory fails to address why one should observe rules of culture and not adhere to universal standards of human rights or even an international response to violations of human rights. ${ }^{277}$ Second, as the antithesis of universalism, cultural relativism is considered morally unfavorable to many because it encourages toleration of cultures that are brutal, prejudiced, and imposing in nature, which might nurture such movements as Nazism. ${ }^{278}$ Essentially, cultural relativism provides little protection for individuals or cultures. In contrast, human rights universalism is largely deemed more morally sound because it values tolerance with qualifications and stands against human rights abuses. ${ }^{279}$

Finally, the UDHR may have largely Western origins, but its merits have been deemed universal to all human beings; this is, perhaps, what truly matters. ${ }^{280}$ It is not imperialistic, because it offers criticism against colonialism; it is not the antithesis of diversity, because it encourages heterogeneity as a way of life as long as human rights and fundamental freedoms are satisfied. Thus, we may argue that the declaration, which has transcended different cultures, is a universal document endorsed by people all over the world. Hence, its universality should not be disregarded.

273. United Nations, Islamic Republic of Iran's National Report Submitted to Human Rights Commission in Accordance with Paragraph 15(a) of Resolution 5/1, UN Doc. A/HRC/WG.6/7/IRN/1, at 130 (2010). 274. "Amnesty International's submission to the Commission on the Status of Women regarding Concerns about Harassment and Imprisonment of Women, Including Rights Defenders and Members of Minorities, in Iran," Amnesty International, 2012, accessed September 1, 2017, https://www.amnesty.org/en/ documents/mde13/054/2012/en/.

275. Jose A. Lindgren Alves, "The Declaration of Human Rights in Postmodernity," Human Rights Quarterly 22 (2000): 498.

276. Milos Bogicevic, "Cultural Relativism and Human Rights," International Journal of Rule of Law, Transnational Justice and Human Rights 3, no. 3 (2013): 153.

277. Ibid.

278. James W. Nickle, Making Sense of Human Rights, 2nd ed. (New York: Blackwell, 2007), 172.

279. John J. Tilley, "Cultural Relativism," Human Rights Quarterly 22, no. 2 (2000): 542-543.

280. Freeman, "Universalism of Human Rights and Cultural Relativism," 53. 


\section{Conclusion}

The history of human rights extends into multiple ancient philosophic and religious traditions, both Western and Eastern, offering a diverse and complex basis upon which the Universal Declaration of Human Rights is founded. Nevertheless, an international framework for human rights protection was not carefully considered until, ironically, one of the most vicious violations of human rights in recorded history. The atrocities of World War II - in particular, the crimes committed by the Nazis during the Holocaust - struck the nerves of humankind and reaffirmed the importance of global cooperation to prevent such atrocities. Owing much to the efforts of smaller powers and civil society, the human rights promise is enshrined within the Charter of the UN, the strongest international mechanism for world peace and order.

The task of drafting the International Bill of Rights was assigned to a small group consisting of five distinguished individuals: Eleanor Roosevelt, P. C. Chang, Charles Malik, René Cassin, and John Peters Humphrey. The drafting and discussion process proved to be tedious. Arguing about everything from broad principles to detailed language, the architects of the declaration diverged in both the ideological and the political sense. As the Cold War loomed, tensions between the US and the USSR intensified and frequently impeded communication between Western and Eastern Bloc states. However, an agreement was ultimately achieved that transcended differences in culture and nationality long enough for the adoption of the Universal Declaration of Human Rights by the UN General Assembly in 1948 without a single dissenting vote.

The significance of the UDHR is clear from both a legal and a moral perspective. The legal imperatives of the declaration, which were initially neglected but are gradually evolving, have been justified through its role informing international customary law as well as its incorporation into various national legislations. Meanwhile, the UDHR's moral imperatives not only inform human rights activism, as illustrated through humanitarian NGOs' practice of naming and shaming, but also inspire changes in the geopolitical landscape, evidenced by the decolonization process and fading of the long Cold War. Perhaps most importantly, the UDHR is observed to embrace many different types of interpretation and, hence, offers great potential for growth over time. Indeed, it is a living document that is adaptable to the changing world more than six decades after its adoption.

However, there remain two core challenges to the UDHR: its enforceability and the concept of cultural relativism. These difficulties, far from weakening the relevance of the declaration in today's society, prove that the declaration has drawn more attention to the issue of human rights. Furthermore, many improvements can be made to the further realization of the document as it continues to evolve over time. The UDHR carries invaluable legal and moral weight. It has and will continue to provide insight into the well-being of all of humankind. 


\section{Bibliography}

Aaronson, Susan Ariel. "Sleeping in Slowly: How Human Rights Concerns Are Penetrating the WTO." World Trade Review 6 (2007): 413-449.

Adolephe, Jane. "The Holy See and the Universal Declaration of Human Rights: Working Towards a Legal Anthropology of Human Rights and Family." Ave Maria Law Review 343 (2006): 343-384.

African Charter of Human Rights and Peoples' Rights, African Commission on Human and Peoples' Rights, 1986. Accessed September 1, 2017, http://www.achpr.org/ instruments/achpr/.

Aggelen, Johannes van. "The Preamble of the United Nations Declaration of Human Rights." Denver Journal of International Law and Policy 28, no. 2 (2000): 129-144.

Alfadhel, Khalifa A. "The GCC Human Rights Declaration: An Instrumentation of Cultural Relativism." Arab Law Quarterly 31 (2017): 89-98.

Alston, Phillip. "The Commission on Human Rights." In The United Nations and Human Rights: A Critical Appraisal, 2nd ed. Oxford: Oxford University Press, 2004.

Alves, Jose A. Lindgren. "The Declaration of Human Rights in Postmodernity." Human Rights Quarterly 22 (2000): 478-500.

Amnesty International, The Human Rights Trend of the Last 60 Years, 2008. Accessed September 1, 2017, https://www.amnesty.org/en/documents/act30/025/2008/ en/.

Amnesty International, Amnesty International's submission to the Commission on the Status of Women regarding Concerns about Harassment and Imprisonment of Women, Including Rights Defenders and Members of Minorities, in Iran. 2012. Accessed September 1, 2017, https://www.amnesty.org/en/documents/mde13/054/2012/ en/.

Anderson, Adrienne. "On Dignity and Whether the Universal Declaration of Human Rights Remains a Place of Refuge After 60 Years." American University International Law Review 25, no. 1 (2009): 115-143.

Araujo, Robert. "Sovereignty, Human Rights, and Self-Determination: The Meaning of International Law." Fordham International Law Journal 24 (2001): 1477-1532.

Arden, The Rt Hon Lady Justice. "Water for All? Developing a Human Right to Water in National and International Law." International Law and Comparative Law Quarterly 65, no. 4 (2016): 771-789.

Aristotle, Aristotle: In Twenty-Three Volumes, translated by J. H. Freese. Cambridge and London: Harvard University Press, 1926. 
Arvan, Marcus. "A Better Dual Theory of Human Rights." The Philosophical Forum 45 (2014): $17-47$.

Ausderan, Jacob. "How Naming and Shaming Affects Human Rights Perceptions in the Shamed Country." Journal of Peace Research 51, no. 1 (2014): 81-95.

Baehr, Peter R. "Controversies in the Current International Human Rights Debate." Human Rights Review 2, no. 1 (2000): 7-32.

Baldwin, Roger. "International Agreements Can Protect Specific Rights." Annals of the American Academy of Political and Social Science 243, no. 1 (January 1946): $134-138$.

Barry, Colin M. and K. Chad Clay. "Avoiding the Spotlight: Human Rights Shaming and Foreign Direct Investment." International Studies Quarterly 57, no. 3 (2013): 532-544.

Beitz, Charles R. "Human Dignity in the Theory of Human Rights: Nothing but a Phrase?" Philosophy 85 Public Affairs 41, no. 3 (2013): 260-290.

Bell, Daniel A. East Meets West: Human Rights and Democracy in East Asia. Princeton: Princeton University Press, 2000.

Bensouda, Fatou. "Forward." In The Law and Practice of the International Criminal Court, edited by Carsten Stahn. Oxford: Oxford University Press, 2015.

Bernstorff, Jochen von. "The Changing Fortunes of the Universal Declaration of Human Rights: Genesis and Symbolic Dimensions of the Turn to Rights in International Law." European Journal of International Law 19, no. 5 (2008): 903-924.

Bielefeldt, Heiner. "Western Versus Islamic Human Rights Conceptions?: A Critique of Cultural Essentialism in Discussion of Human Rights." Political Theory 28, no. 1, (2000): 90-121.

Black, Allida M. "Eleanor Roosevelt and the Universal Declaration of Human Rights." OAH Magazine of History 22, no. 2 (2008): 34-37.

Black, Allida M. Casting Her Own Shadow: Eleanor Roosevelt and the Shaping of Postwar Liberalism. New York: Columbia University Press, 1996.

Bleicher, Samuel A. "The Legal Significance of Re-Citation of General Assembly Resolutions." American Journal of International Law 63 (1969): 444-478.

Bogicevic, Milos. "Cultural Relativism and Human Rights." International Journal of Rule of Law, Transnational Justice and Human Rights 3, no. 3 (2013): 151-156.

Buergenthal, Thomas, Dianh Shelton, and David P Stewart. "International Human Rights in a Nutshell." George Washington Legal Studies Research Paper no. 2013-34 (2009): $1-28$. 
Burke, Roland. "Flat Effect? Revisiting Emotions in the Historiography of Human Rights." Journal of Human Rights 16, no. 2 (2015): 123-141.

Burke, Roland. Decolonization and the Evolution of International Human Rights. Philadelphia: University of Pennsylvania Press, 2010.

Carey, Sabine C. The Politics of Human Rights: The Quest for Dignity. Cambridge, UK: Cambridge University Press, 2010.

Cassin, René. La Pensée et l'Action. Paris: Lalou, 1972.

Chan, Joseph C.W. "Confucianism and Human Rights." In Religion and Human Rights: An Introduction, edited by John Witte Jr. and M. Christian Green. New York: Oxford University Press, 2011.

Cheng, Tai-Heng. "The Universal Declaration of Human Rights at Sixty: Is It Still Rights for the United States?" Cornell International Law Journal 41, no. 2 (2008): 251-305.

Churchill, Winston. "The Sinews of Peace ('Iron Curtain Speech')." International Churchill Society. March 5, 1946. Accessed September 1, 2017, https ://www . winstonchurchill. org/resources/speeches/1946-1963-elder-statesman/the-sinews-of-peace.

Cmiel, Kenneth. "The Recent History of Human Rights." American Historical Review 109 (2004): 117-135.

Constantinides, Aristoteles. "Questioning the Universal Relevance of the Universal Declaration of Human Rights." Harvard Human Rights Journal 15 (2000): 101-125.

Cronin-Furman, Kathleen Renee. "60 Years of the Universal Declaration of Human Rights: Towards an Individual Responsibility to Protect." American University International Law Review 25 (2010): 175-198.

Darraj, Susan Muaddi. Milestones in Modern World History: The Universal Declaration of Human Rights Langhome: Chelsea House, 2010.

DeMeritt, Jacqueline H. R. "International Organizations and Government Killing: Does Naming and Shaming Save Lives?" International Interactions 38, no. 5 (2012): 597-621.

Dicker, Richard. "International Criminal Court and Double Standards of International Justice." In The Law and Practice of the International Criminal Court, edited by Carsten Stahn. Oxford: Oxford University Press, 2015.

Dolinger, Jacob. "The Failure of the Universal Declaration of Human Rights." University of Miami Inter-American Law Review 47 (2016): 164-199.

Donnelly, Jack. Universal Human Rights in Theory and Practice. Ithaca: Cornell University Press, 2013. 
Eberl, Jason T., Eleanor D. Kinney, and Matthew J. Williams. "Foundation for A Natural Right to Health Care." Journal of Medicine and Philosophy 36 (2011): 537-557.

Eckel, Jan. "Human Rights and Decolonization: New Perspectives and Open Questions." Humanity: An International Journal of Human Rights, Humanitarianism, and Development 1, no. 1 (2010): 111-135.

Elkins, Zachary, Tom Ginsburg, Beth Simmons. "Getting to Rights: Treaty Ratification, Constitutional Convergence, and Human Rights Practice." Harvard International Law Journal 54, no. 1 (2013): 61-95.

Evans, Mark. "Just War, Democracy, Democratic Peace." European Journal of Political Theory 11, no. 2 (2011): 191-208.

Freeman, Michal. "Universalism of Human Rights and Cultural Relativism." In Routledge Handbook of International Human Rights Law, edited by Scott Sheeran and Sir Nigel Rodley. New York: Routledge, 2013.

Fuentes, Carlos Iván, René Provost, and Samuel G. Walker. "E Pluribus Unum-Bhinneka Tunggal Ika? Universal Human Rights and the Fragmentation of International Law." In Dialogue on Human Rights and Legal Pluralism, edited by R. Provost and C. Sheppard. New York: Springer, 2013.

Gable, Lance. "The Proliferation of Human Rights in Global Health Governance." Journal of Law, Medicine 8 Ethics 3, no. 1 (2009): 534-544.

Gammeltoft-Hansen, Thomas and Hans Gammeltoft-Hansen. "The Right to SeekRevisited. On the UN Human Rights Declaration Article 14 and Access to Asylum Procedures in the EU." European Journal of Migration and Law 10 (2008): 439-459.

Gardbaum, Stephen. "Human Rights as International Constitutional Rights." European Journal of International Law 19, no. 4 (2008): 749-768.

Gardner, Richard N. "The Genesis of the Declaration: A Fresh Examination." Pace International Law Review 27 (1999): 27-65.

Ghandhi, Sandy. "The International Bill of Rights and the European Conventions on Human Rights," Legal Information Management 6 (2006).

Glendon, Mary Ann. "The Rule of Law in the Universal Declaration of Human Rights." Northwestern Journal of International Human Rights 1 (2004): 1-19.

Glendon, Mary Ann. A World Made New: Eleanor Roosevelt and the Universal Declaration of Human Rights. New York: Random House, 2001.

Glensy, Rex D. "The Right to Dignity." Columbia Human Rights Law Review 43 (2011): 65-142.

Gopalan, Sandeep. "Alternative Sanctions and Social Norms in International Law: The Case of Abu Ghraib." Michigan State Law Review (2007): 785-839. 
Gouge, Olympe de. "Declaration of the Rights of Women and the Female Citizen." College of Staten Island Library: American Studies Program (1791).

Grandin, Greg. "The Liberal Traditions in the Americas: Rights, Sovereignty, and the Origins of Liberal Multilateralism." American Historical Review 117, no. 1 (2012): 68-91.

Green, James Frederick. The United Nations and Human Rights. Washington, D.C.: Brookings Institution, 1956.

Hannum, Hurst. "The Status of the Universal Declaration of Human Rights in National and International Law." Georgia Journal of International and Comparative Law 25 (1995): 287-397.

Hendrix, Cullen S. and Wendy H. Wong. "What is the Pen Truly Mighty? Regime Type and the Efficacy of Naming and Shaming in Curbing Human Rights Abuses." British Journal of Political Science 43, no. 3 (2013): 651-672.

Henkin, Louis. "Human Rights and State Sovereignty." Georgia Journal of International and Comparative Law 25, no. 31 (1995): 31-45.

Higgins, Noelle. "Advancing the Rights of Minorities and Indigenous Peoples: Getting UN Attention Via the Universal Periodic Review." Netherlands Quarterly of Human Rights 32, no. 4 (2014): 379-407.

Higgins, Rosalyn. "Conceptual Thinking About the Individual in International Law." British Journal of International Studies 4, no. 1 (1978): 1-19.

Hill, Dilys M. "Rights and Their Realisation." In Economic, Social, and Cultural Rights: Progress and Achievement, ed. Ralph Beddard and Dilys M. Hill. New York: Palgrave Macmillan, 1992.

Hill, Lisa. "Stoic Cosmopolitanism and the Birth of Universal Rights." American Political Science Association 2013 Annual Meeting Paper (2013): 1-30.

Hoover, Joe. "Rereading the Universal Declaration of Human Rights: Plurality and Contestation, Not Consensus." Journal of Human Rights 12 (2013): 217-241.

Humphrey, John P. Human Rights and United Nations: A Great Adventure. New York: Transnational, 1984.

Humphrey, John P. On the Edge of Greatness: The Diaries of John Humphrey, First Director of the United Nations Division of Human Rights, vol. 1,1948-1949, edited by A. J. Hobbins. Montreal: McGill University Libraries, 1994.

Ibhawoh, Bonny. "Defining Persecution and Protection: The Cultural Relativism Debate and the Rights of Refugees." In Problems of Protection: The UNHCR, Refugees, and Human Rights, edited by Niklaus Steiner, Mark Gibney, and Gil Loescher. New York and London: Routledge, 2003. 
Institut de droit international. "Declaration of the International Rights of Man." American Journal of International Law 35 (1941): 664.

Irvin-Erickson, Douglas. "Protection from Whom? Tensions, Contradictions, and Potential in the Responsibility to Protect." In Rethinking Security in the Twenty-First Century, edited by Daniel Jacob. New York: Palgrave Macmillan, 2017.

Ishay, Micheline R. The History of Human Rights: From Ancient Times to the Globalization Era. Berkeley: University of California Press, 2008.

Jacobson, Harold K. "Structuring the Global System: American Contributions to International Organization." The ANNALS of the American Academy of Political and Social Science 428, no. 1 (1976): 79-90.

James W. Nickle, Making Sense of Human Rights, 2nd ed. (New York: Blackwell, 2007), 172.

Johnson, M. Glen and Janusz Symonides. The Universal Declaration of Human Rights: A History of Its Creation and Implementation 1948-1998. Paris: UNESCO Publishing, 1998.

Jones, John F. and James Herbert Williams. "Summary and Conclusion: A View from the Bridge." In Conflict and Human Security in Africa: Kenya in Perspective, edited by Asfaw Kumssa, John F. Jones, and James Herbert Williams. New York: Palgrave Macmillan, 2011.

JUSTICE Constitution Committee of British Section of the International Commission of Jurists. "A British Bill of Rights: Informing the Debate. 2007. Accessed September 1, 2017, http://www. statewatch.org/news/2007/nov/uk-justice-bill-of-rights-rep. pdf.

Kapferer, Sibylle. "Article 14(2) of the Universal Declaration of Human Rights and Exclusion from International Refugee Protection." Refugee Survey Quarterly 27, no. 3, (2008): 53-75.

Keane, David. "Survival of the Fairest? Evolution and the Geneticization of Rights." Oxford Journal of Legal Studies 30, no. 3 (2010): 467-494.

Kelly, Brendan Desmond. "Human Rights Protection for the Mentally Ill though Mental Health Law in England and Ireland." (PhD diss., University of Leicester, 2012): $1-345$.

Keown, Damien. "Are There "Human Rights" in Buddhism?" In Buddhism and Human Rights, edited by Damien Keown, Charles S. Prebish, and Wayne R. Husted. Richmond. Surrey: Curzon Press, 1998.

Koivurova, Timo, Sébastien Duyck, and Leena Heinämäki. "Climate Changes and Human Rights." In Climate Change and the Law, Ius Gentium: Comparative, edited by E. J. Hollo. New York: Springer, 2013. 
Korey, William. NGO's and the Universal Declaration of Human Rights: A Curious Grapevine. London: Palgrave Macmillan, 2004.

Krain, Matthew. "J'accuse! Does Naming and Shaming Perpetrators Reduce the Severity of Genocides or Politicides?" International Studies Quarterly 56, no. 3 (2012): 574-589.

Lauren, Paul Gordon. The Evolution of International Human Rights: Vision Seen. Philadelphia: University of Pennsylvania Press, 2011.

Lauterpacht, Hersch. "The Universal Declaration of Human Rights." British Yearbook of International Law 25 (1948): 354-381.

Lauterpacht, Hersch. International Law and Human Rights. London: Stevens \& Son, 1950.

Law, David S. and Mila Versteeg. "The Declining Influence of the United States Constitution." New York University Law Review 87 (2012): 762-858.

Lee, Rebecca. "Forced Sterilization and Mandatory Divorce: How A Majority of Council of Europe Member States' Laws Regarding Gender Identity Violate the Internationally and Regionally Established Human Rights of Trans People." Berkeley International Journal of Law 33 (2015): 114-152.

Legal Consequences for States of the Continued Presence of South Africa in Namibia (South West Africa) Notwithstanding Security Council Resolution 276 (1970), ICJ Reports. American Journal of International Law 66, no. 1 (1972): 145-183.

Lillich, Richard B. "The Growing Importance of the Customary International Human Rights Law." Georgia Journal of International and Comparative Law 25 (1996): $1-30$.

Linebaugh, Peter. The Magna Carta Manifesto: Liberties and Commons for All. Berkeley: University of California Press, 2008.

Linowitz, Sol, Charles H. Malik, and Daniel Parker. The Creative Interface: International Business-Governmental Relations, vol. 2. Washington D.C.: American University, 1970.

Lippman, Matthew. "Human Rights Revisited: The Protection of Human Rights under the International Covenant on Civil and Political Rights." Netherlands International Law Review 26 (1979): 221-277.

Locke, John. Locke: Two Treaties of Government student edition. Cambridge: Cambridge University Press, 1988.

Maclnnis, Luke. "Agency and Attitude: Kant's Purposive Conception of Human Rights." Philosophy and Social Criticism 42, no. 3 (2016): 289-319.

Malik, Charles. "1948 - The Drafting of the Universal Declaration of Human Rights." UN Bulletin on Humanitarian Rights 97 (1986). 
Maoz, Asber. "Can Judaism Serve as a Source of Human Rights?" Heidelberg Journal of International Law 64 (2004): 677-722.

Maoz, Asher. "War and Peace-An Israeli Perspective." Constitutional Forum 24, no. 2 (2005): 35-76.

Marmor, Andrei and Alexander Sarch, "The Nature of Law," in The Stanford Encyclopedia of Philosophy (Fall 2015 Edition), ed. Edward N. Zalta, last modified Fall 2015. Accessed September 1, 2017, https://plato.stanford.edu/archives/fall2015/ entries/lawphil-nature.

Mayer, Ann Elizabeth. "Human Rights as a Dimension of CSR: The Blurred Lines Between Legal and Non-Legal Categories." Journal of Business Ethnics 88 (2009): 561-577.

Mayers, David. "Humanity in 1948: The Genocide Convention and Universal Declaration of Human Rights," Diplomacy $\&$ Statecraft 26 (2015): 446-472.

McFarland, Sam. "The Slow Creation of Humanity." Political Psychology 32, no. 1 (2011): $1-20$.

McGlodrick, Dominic. The Human Rights Committee: Its Role in the Development on Civil and Political Rights. Oxford: Clarendon Press, 1991.

McInerny, Ralph and John O'Callaghan. "Saint Thomas Aquinas." The Stanford Encyclopedia of Philosophy. Last edited Winter 2016. Accessed September 1, 2017, https://plato.stanford.edu/entries/aquinas/.

McMaster, Amy J. "Human Rights at the Crossroads: When East Meets West." Vermont Law Review 29 (2004): 109-146.

Mehar, Iftikhar Ahmed. Al-Islam: Inception to Conclusion. Bloomington: Authorhouse, 2003.

Memorandum of Conversation between Mrs. Roosevelt, Senator Austin, and Messrs Ross, Winslow and Hendrick, Box 4587, ER Paper, 1947.

Meyersfeld, Bonita. "A Theory of Domestic Violence in International Law." JSD Thesis, Yale Law School, 2016.

Moncel, Remi. "Dangerous Experiments: Scientific Integrity in International Environment Adjudications after the ICJ's Decision in Whaling in the Antarctic." Ecology Law Quarterly 42, no. 2 (2015): 305-345.

Monteiro, Reis. Ethics of Human Rights. Heidelberg: Springer International Publishing, 2014.

Moran, Gabriel. "Human Rights Need a Human Tradition." CrossCurrents 62, no. 1 (2012): 75-88. 
Morsink, Johannes. The Universal Declaration of Human Rights: Origins, Drafting, and Intent. Philadelphia: University of Pennsylvania Press, 1999.

Mower, A. Glenn Jr. The United States, the United Nations, and Human Rights: The Eleanor Roosevelt and Jimmy Carter Eras. Westport, Connecticut: Greenwood Press, 1979.

Moyn, Samuel. "Substance, Scale, and Salience: The Recent Historiography of Human Rights." The Annual Review of Law and Social Science 8 (2012): 123-140.

Moyn, Samuel. Human Rights and the Uses of History. New York and London: Verso, 2014.

Mule, Nick J., Maryam Khan, and Cameron McKenzie. "The Growing Presence of LGBTQIs at the UN: Arguments and Counter-arguments." International Social Work (2017): 1-28.

Murdie, Amanda M. and David R. Davis. "Shaming and Blaming: Using Events Data to Assess the Impact of Human Rights INGOs." International Studies Quarterly 56 (2012): 1-16.

Mutua, Makau. Human Rights NGOs in East Africa: Political and Normative Tensions. Philadelphia: University of Pennsylvania Press, 2009.

Neier, Aryeh. The International Human Rights Movement: A History. Princeton: Princeton University Press, 2012.

Nolan, Cathal J. "Road to the Charter: America, Liberty, and the Founding of the United Nations." Paradigms 3, no. 1 (1989): 24-37.

Normand, Roger and Sarah Zaidi. Human in the U.N.: The Political History of Universal Justice. United Nations Intellectual History Project. Bloomington: Indiana University Press, 2008.

Novak, Michael. "The Judeo-Christian Foundation of Human Dignity, Personal Liberty, and the Concept of the Person." Journal of Markets \& Morality 1, no. 2 (1998): 107-121.

Nzelibe, Jide. "Courting Genocide: The Unintended Effects of Humanitarian Intervention." Northwestern University School of Law, Public and Legal Theory Series 8, no. 36 (2008): 1-64.

Osiatynski, Wiktor. Human Rights and Their Limits. Cambridge, UK: Cambridge University Press, 2009.

Paul, James C.N. and Roktim Kaushik. "Urban Poverty and the Right to a Decent Habitat as Established by International Human Rights Law." Rutgers Law Review 63, no. 3 (2011): 905-939. 
Pedretti, Ramona. Immunity of Heads of State and State Officials for International Crimes. Leiden: Martinus Nijhoff, 2014.

Pendas, Devin O. "Towards a New Politics? On Recent Historiography of Human Rights." Contemporary European History 21, no. 1 (2012): 95-111.

Pisano, Attilio. "Human Rights and Sovereignty in the ASEAN Path Towards a Human Rights Declaration." Human Rights Review 15, no. 4 (2014): 391-411.

Polsdofer, Stephan. "Pride and Prejudiced: Russia's Anti-Gay Propaganda Law Violates the European Conventions on Human Rights." American University International Law Review 29, no. 5 (2014): 1069-1096.

Proposal for the Establishment of a General International Organization, Pamphlet No. 4, Pillars of Peace. In Documents Pertaining to American Interest in Establishing a Lasting World Peace: January 1941-February 1946. Fort George G. Meade: Army Information School, 1946.

Relly, Jeannie E. "Freedom of Information Laws and Global Diffusion: Testing Roger's Model." Journalism \& Mass Communication Quarterly 89, no. 3 (2012): 431-457.

Reus-Smit, Christian. "Human Rights and the Social Construction of Sovereignty." Review of International Studies 27 (2001): 519-538.

Robinson, Mary. "The Universal Declaration of Human Rights: A Living Document." Australian Journal of International Affairs 52, no. 2 (1998): 117-120.

Roosevelt, Eleanor. "The Promise of Human Rights." Foreign Affairs, 1948.

Roosevelt, Franklin D. "Message to Congress." January 6, 1941. Accessed September 1, 2017, https://fdrlibrary.org/four-freedoms.

Roosevelt, Franklin D. and Churchill, Winston S. Atlantic Charter. John Wiley \& Sons, Ltd., 1941.

Roosevelt, Franklin D. "The Pubic Papers and Addresses of Franklin D. Roosevelt: Humanity on the Defensive." American Historical Review 55, no. 4 (1942): 1-552.

Rosen, Michael. Dignity: Its History and Meaning. Cambridge, MA: Harvard University Press, 2012.

Saito, Natsu Taylor. "Justice Held Hostage: U.S. Disregard for International Law in the World War II Internment of Japanese Peruvian-Case Study." Boston College Third World Law Journal 19, no. 1 (1998): 275-348.

Sankey, Mara Elizabeth. "Promoting Democracy? The Role of Transnational Non-State Actors in Inter-American Relations 1980-1993." PhD diss., University College London, 2016. 
Schabas, William A. The Universal Declaration of Human Rights: The Travaux Preparatoires, vol. 1. Cambridge: Cambridge University Press, 2013.

Schabas, William A. "The Rights to Life." In Oxford Handbook of International Law in Armed Conflict, edited by Andrew Clapham and Paola Gaeta. Oxford: Oxford University Press, 2014.

Schmitt, C. B. The Cambridge History of Renaissance Philosophy. Cambridge: Cambridge University Press, 1988.

Schutter, Olivier De. International Human Rights Law: Cases, Materials, Commentary. Cambridge: Cambridge University Press, 2014.

Schwelb, Egon. "Human Rights and the International Community." In The Roots and Growth of the Universal Declaration of Human Rights, edited by Roger Stenson Clark. The Hague: Martinus Nijhoff, 1963.

Schwelb, Egon. "The Influence of the Universal Declaration of Human Rights on International and National Law," Proceedings of the American Society of International Law 53 (1959): 217-229.

Sellars, Kirsten. The Rise and Rise of Human Rights. Thrupp: Sutton, 2002.

Simpson, Brad. "The Biafran Secession and the Limits of Self-determination." Journal of Genocide Research 16, no. 2-3, (2014): 337-354.

Snyder, Sarah B. Human Rights Activism and the End of the Cold War: A Transnational History of the Helsinki Network. New York: Cambridge University Press, 2011.

Sommerville, Donald, and Ian Westwell. The Complete Illustrated History of World War II: An Authoritative Account of One of the Deadliest Conflicts in Human History, with Analysis of Decisive Encounters and Landmark Engagements. London: Lorenz Books, 2008.

Staffen, Marcio Ricardo. "The Legal Development of the Notion of Human Dignity in the Constitutional Jurisprudence." Revista Brasileira de Direito 12, no. 2 (2016): 108-126.

Stalin, Joseph P. "Speech Delivered by J. V. Stalin at a Meeting of Voters of the Stalin Electoral District." 1946. Accessed September 1, 2017, https ://www . marxists .org/ reference/archive/stalin/works/1937/12/election/index.htm.

Sun, Pinghua. "Confucian Philosophy and Its Historical Contributions to Human Rights." In Human Rights Protection System in China. New York: Springer, 2014.

Swepston, Lee. "The International Labour Organization and International Human Rights System." In Routledge Handbook of International Human Rights Law, edited by Scott Sheeran and Sir Nigel Rodley. London and New York: Routledge, 2013.

Talbott, W.J. Which Rights should be Universal? Oxford: Oxford University Press, 2005. 
Tatsiy, Vasily. "The Universal Declaration of Human Rights: The Worldwide Humanism Manifesto." Law of Ukraine, no. 5-6 (2011): 28-34.

Thomas, Ann Van Wynen and A.J. Thomas Jr. "Human Rights and Organizations of American States." Santa Clara Lawyer 12 (1972): 319-376.

Tilley, John J. "Cultural Relativism." Human Rights Quarterly 22, no. 2 (2000): 501-547.

Timmermann, Cristian. "Sharing in or Benefiting from Scientific Advancement?" Science and Engineering Ethics 20 (2014): 111-133.

Tomuschat, Christian. Human Rights Between Idealism and Realism. Oxford: Oxford University Press, Oxford, 2003.

Truitt, Andrew. "Ancient Roots and Modern Offshoots: The Development of International Human Rights." Regents Journal of International Law 7 (2009): 199.

Twiss, Sumner B. "History, Human Rights, and Globalization." Journal of Religious Ethics 32, no. 1 (2004): 39-70.

Twiss, Sumner. "Confucian ethics, concept-clusters, and human rights." In Polishing the Chinese Mirror: Essay in Honor of Henry Rosemont, Jr., edited by Marthe Chandler and Ronnie Littlejohn. New York: Global Scholarly Publication, 2007.

Unger, Anna, Stuart Wallace, and Tamas Dezso Ziegler. "The Role of Human Rights in EU-US Bilateral Relations." FRAME Deliverable 6, no. 5 (2016): 1-216.

United Nations, Amendments Proposed by the Union of Soviet Socialist Republics to the Draft Declaration, UN Doc. A/784, 1948.

United Nations, Collation of the Comments of Government on the Draft International Declaration on Human Rights, Draft International Covenant on Human Rights and the Question of Implementation, UN Doc. E/CN.4/85, 1948.

United Nations, Commission on Human Rights, Draft Report of the Working Group on Implementation, UN Doc. E/CN.4/53, 1947.

United Nations, Commission on Human Rights, Summary of Meetings, UN Doc. E/HR. 9, 1946.

United Nations, Commission on Human Rights, Summary Record of Eighty-First Meeting, UN Doc. E/CN.4/SR.81, 1948.

United Nations, Commission on Human Rights, Summary Record of the Twelfth Meeting, UN Doc. E/CN.4/SR.12, 1947.

United Nations, Commission on Human Rights, Summary Record of the Eighth Meeting, UN Doc. E/CN.4/SR.8, 1947. 
United Nations, Commission on Human Rights, Summary Record of the Seventy-Second Meeting, UN Doc. E/CN.4/SR.72, 1948.

United Nations, Commission on Human Rights, Summary Record of the Twenty-Eighth Meeting, UN Doc. E/CN.4/SR.28, 1947.

United Nations, Commission on Status of Women, Summary Record of the Ninth Meeting, UN Doc. E./CN.6/SR.28, 1948.

United Nations, Declaration on the Granting of Independence to Colonial Countries, UN Doc. A/Res. 1514(XV), OP 7.

United Nations, Drafting Committee of the Commission on Human Rights, Summary Record of the First Meeting, UN Doc. E/CN.4/AC.1/SR/1, 1947.

United Nations, Economic and Social Council, Summary Record of the Two Hundred and Fifteenth Meeting, UN Doc. E/SR.215, 1948.

United Nations, General Assembly, Official Record of the Second Session, UN Doc. A/519, 1947.

United Nations, General Assembly, The Universal Declaration of Human Rights, 1948.

United Nations, General Assembly, Verbatim Record of the Hundred and Eightieth Plenary Meeting, UN Doc. A/PV.180, 1948.

United Nations, General Assembly, Verbatim Record of the Hundred and Eighty-Third Plenary Meeting, UN Doc. A/PV.183, 1948.

United Nations, International Conference on Human Rights, Resolution adopted on the Report of the Third Committee, UN Doc. A/RES/2442(XXIII), 1968.

United Nations, Islamic Republic of Iran's National Report Submitted to Human Rights Commission in Accordance with Paragraph 15(a) of Resolution 5/1, UN Doc. A/HRC/WG.6/7/IRN/ 2010.

United Nations, Note by Representative of Canada, UN Doc. E/965, 1948.

United Nations, Proclamation of Tehran, Final Act of the International Conference on Human Rights, UN Doc. A/CONF.32/41, 1968.

United Nations, Report of the Commission on Human Rights to the Second Session of the Economic and Social Council, UN Doc. E/38, 1946.

United Nations, Report of the Drafting Committee to the Commission on Human Rights, UN Doc. E/CN.4/21, 1947.

United Nations, Report of the Drafting Sub-Committee Consisting of the Representatives of Chile, China, United States of America, Union of Soviet Socialist Republics, on Article 5,6,7, of the International Declaration on Human Rights, UN Doc. E/CN.4/82/Add.11, 1948. 
United Nations, Report of the Preparatory Commission of the United Nations, 1946. Accessed September 1, 2017, http://dag.un.org/handle/11176/248329.

United Nations, Report of the Third Session of the Commission on Human Rights, UN Doc. E/800, 1948.

United Nations, Second Session of Drafting Committee, Summary Record of the Twentieth Meeting, UN Doc. E/CN.4/AC.1/SR.20, 1948.

United Nations, Speech by Mr. A. N. Pavlov, Representative of the Union of Soviet Socialist Republics in the Drafting Committee of the Commission on Human Rights, UN Doc. E/CN.4/AC.1/29, 1948.

United Nations, The Third Committee, Summary Record of the Hundred and Sixty-Fifth Meeting, UN Doc. A/C.3/SR.165, 1948.

United Nations, Third Committee, Summary Record of the Hundred and Seventy-Ninth Meeting, UN Doc. A/C.3/SR.179, 1948.

United Nations, Third Committee, Summary Record of the Hundred and Sixty-Third Meeting, UN Doc. A/C.3/SR.163, 1948.

United Nations, Treatment of People of Indian Origin in the Union of South Africa, UN Doc. A/Res. 265(III), OP 1.

United Nations, U.N. Charter. Accessed September 1, 2017, http://www.un.org/en/ sections/un-charter/chapter-i/index.html.

United Nations, Union of Soviet Socialist Republic, Amendments to the Draft Declaration proposed by the Third Committee, UN Doc. A/784, 1948.

United Nations, United Kingdom: Amendment to Article 3 of the Draft Declaration proposed by the Third Committee, UN Doc. A/778/Rev.1.

United States Diplomatic and Consular Staff in Tehran (United States of America v. Iran). Judgment, ICJ Report, 1980.

Vennesson, Pascal. "War Under Transnational Surveillance: Framing Ambiguity and the Politics of Shame." Review of International Studies 40 (2014): 25-51.

Vyver, Johan D. van der. "A Reality Check: The Binding Force of Economic and Social Rights Listed in the Universal Declaration of Human Rights." Hamline Journal of Public Law and Policy 30 (2008): 125-174.

Wabwile, Michael Nyongesa. "Legal Protection of Social and Economic Rights of Children in Developing Countries: Reassessing International Cooperation and Responsibility." PhD diss., University of Leicester, 2009. 
Wallbott, Linda and Andrea Schapper. "Negotiating by Own Standards? The Use and Validity of Human Rights Norms in UN Climate Negotiations." International Environmental Agreement: Politics, Law, and Economics 17 (2017): 209.

Wang, Carol. "Rule of Law in Afghanistan: Enabling a Constitutional Framework for Local Accountability." Harvard International Law Journal 55, no. 1 (2014): 212-249.

Wiesel, Elie. "Voices: A Tribute to Human Rights." In The Universal Declaration of Human Rights Fifty Years and Beyond, edited by Yael Danieli. Amityville: Baywood, 1999.

William, Alfred and Brain Simpson. Human Rights and the End of the Empire: Britain and the Genesis of the European Convention. Oxford: Oxford University Press, 2004.

Winter, Jay and Antoine Prost. René Cassin and Human Rights: From the Great War to the Universal Declaration. Cambridge: Cambridge University Press, 2013.

Witte, Bruno De. "The Protection of Linguistic Diversity Through Fundamental Rights." European University Institute (1985): 1-675.

World Conference on Human Rights in Vienna. "Vienna Declaration and Programme of Action." 1993. Accessed September 1, 2017, http://www . ohchr.org/EN/Prof essionalInterest/ Pages/Vienna. aspx.

Writte Jr., John. "Law, Religion, and Human Rights." Columbia Human Rights Law Review 28, no.1 (1996): 1-31.

Writte Jr., John. "Religion." In The Oxford Handbook of International Human Rights Law, edited by Dinah Shelton, 9-31. New York/Oxford: Oxford University Press, 2013.

Yale University, The Avalon Project at the Yale Law School: Documents in Law, History and Diplomacy. "The Covenant of the League of Nations." Last modified 2008. Accessed September 1, 2017, http://avalon.law.yale.edu/20th_century/leagcov . asp.

Yoo, John. "Fixing Failed States." California Law Review 99 (2011): 95-150.

Zaremby, Justin. "On the Uses and Disadvantages of History for Human Rights Law: Reading Samuel Moyn's The Last Utopia: Human Rights in History." Yale Human Rights and Development Journal 15 (2012): 155-177. 